\title{
Current status and future perspectives: TSPO in steroid neuroendocrinology
}

\author{
Vimal Selvaraj and Lan $\mathbf{N}$ Tu \\ Department of Animal Science, Cornell University, Ithaca, New York, USA
}

Correspondence

should be addressed

to $V$ Selvaraj

Email

vs88@cornell.edu

\begin{abstract}
The mitochondrial translocator protein (TSPO), previously known as the peripheral benzodiazepine receptor (PBR), has received significant attention both as a diagnostic biomarker and as a therapeutic target for different neuronal disease pathologies. Recently, its functional basis believed to be mediating mitochondrial cholesterol import for steroid hormone production has been refuted by studies examining both in vivo and in vitro genetic Tspo-deficient models. As a result, there now exists a fundamental gap in the understanding of TSPO function in the nervous system, and its putative pharmacology in neurosteroid production. In this review, we discuss several recent findings in steroidogenic cells that are in direct contradiction to previous studies, and necessitate a re-examination of the purported role for TSPO in de novo neurosteroid biosynthesis. We critically examine the pharmacological effects of different TSPObinding drugs with particular focus on studies that measure neurosteroid levels. We highlight the basis of key misconceptions regarding TSPO that continue to pervade the literature, and the need for interpretation with caution to avoid negative impacts. We also summarize the emerging perspectives that point to new directions that need to be investigated for understanding the molecular function of TSPO, only after which the true potential of this therapeutic target in medicine may be realized.
\end{abstract}

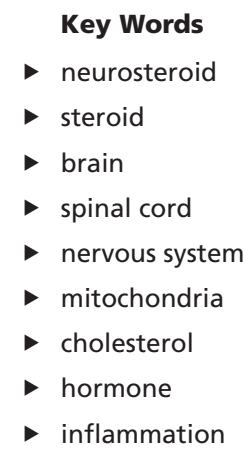

Journal of Endocrinology (2016) 230, R1-R30

\section{Introduction}

For more than 75 years, it has been recognized that steroid hormones can be potent modulators of nervous system function. Specific steroid-mediated mechanisms are capable of exerting a variety of physiological effects that can be either acute or persistent on different neurological processes. These include: specific gene expression by binding to nuclear receptors, modulation of neurotransmission via action on specific membrane receptors, development and establishment of specific neural circuitry, ameliorating neuroinflammation, and improving aspects of neuroregeneration. Due to their lipophilic nature that allows crossing of the blood-brain barrier, steroids from the adrenals or gonads can directly act on nervous system targets, or be converted to 'neuroactive' metabolites that elicit specific actions. Synthesis of steroids de novo in the nervous system was first demonstrated in 1981 (Corpechot et al. 1981); it was discovered that elimination of peripheral steroid sources by gonadectomy, adrenalectomy or removal of trophic stimuli through hypophysectomy only had modest effects on steroid levels in the central nervous system (CNS) (Corpechot et al. 1981, 1983, Robel et al. 1987, Jo et al. 1989). The term 'neurosteroid' was introduced to describe steroids locally synthesized by cells of the CNS and

Published by Bioscientifica Ltd. 
peripheral nervous system (PNS). Local concentrations of neurosteroids in the nervous system were found to exceed levels present in the blood stream, and differed based on brain regions examined (Cheney et al. 1995). Therefore, neurosteroid functions with a regional or localized concentrations, not achievable by peripheral steroids have been of particular mechanistic interest in studying nervous system homeostasis and pathologies.

Synthesis of steroids in the CNS and PNS is known to begin early during development and remain into adulthood (Compagnone et al. 1995, Pezzi et al. 2003, King et al. 2004). In these tissues, steroidogenesis does not occur in dedicated cells, but has been reported to be associated with several of the excitable and supporting cell types including neurons (different types), astrocytes, oligodendrocytes, Schwann cells and their progenitors (Le Goascogne et al. 1987, Hu et al. 1987b, Jung-Testas et al. 1989, Koenig et al. 1995, King et al. 2002, Sierra et al. 2003, Saalmann et al. 2007). In addition, specialized sensory elements, such as ocular neuro-retinal cells (Provost et al. 2003) and taste buds present in circumvallate papillae (Toyoshima et al. 2007), have also been reported to be capable of steroid production. Biosynthesis of neurosteroids in nervous tissue appears to be evolutionarily conserved across several vertebrate species examined (Tsutsui et al. 1999). However, interpretation of steroid mechanisms in the CNS and PNS presents a high degree of complexity not only because of the different cell types and potential actions, but also because of the nature and activity of the different neurosteroids that are being produced. Moreover, localization of neurosteroid production to specific regions within the nervous system and/or pathologies directly affects functional outcomes.

As a marker for localizing neurosteroid production, the mitochondrial translocator protein (TSPO) expression has been used in numerous studies. However, its purported steroidogenic function has been refuted in recent studies, challenging the basis of this interpretation in the nervous system. In this review, we carefully consider the past and assess the current state of understanding TSPO function.

\section{Biosynthesis of neurosteroids}

Neurosteroids act as paracrine or autocrine modulators of a variety of neuronal functions and activities. The primary neurosteroids whose functions have been studied can be broadly described as follows: 3 $\beta$-hydroxysteroids (pregnenolone (PREG), pregnenolone sulfate (PS), dehydroepiandrosterone (DHEA) and dehydroepiandrosterone sulfate (DHEA-S)); pregnane steroids, which are progesterone (PROG) and progesterone metabolites (dihydroprogesterone (DHP), allopregnanolone (ALLO) and pregnanolone (THP), deoxycorticosterone (DOC), dihydrodeoxycorticosterone (DHDOC) and tetrahydrodeoxycorticosterone (THDOC)); and androstanes (androstanol and androsterone) (Fig. 1). Several recent reviews have addressed the topic of neurosteroids and their importance in nervous system physiology and pathology that include cognition, mood,

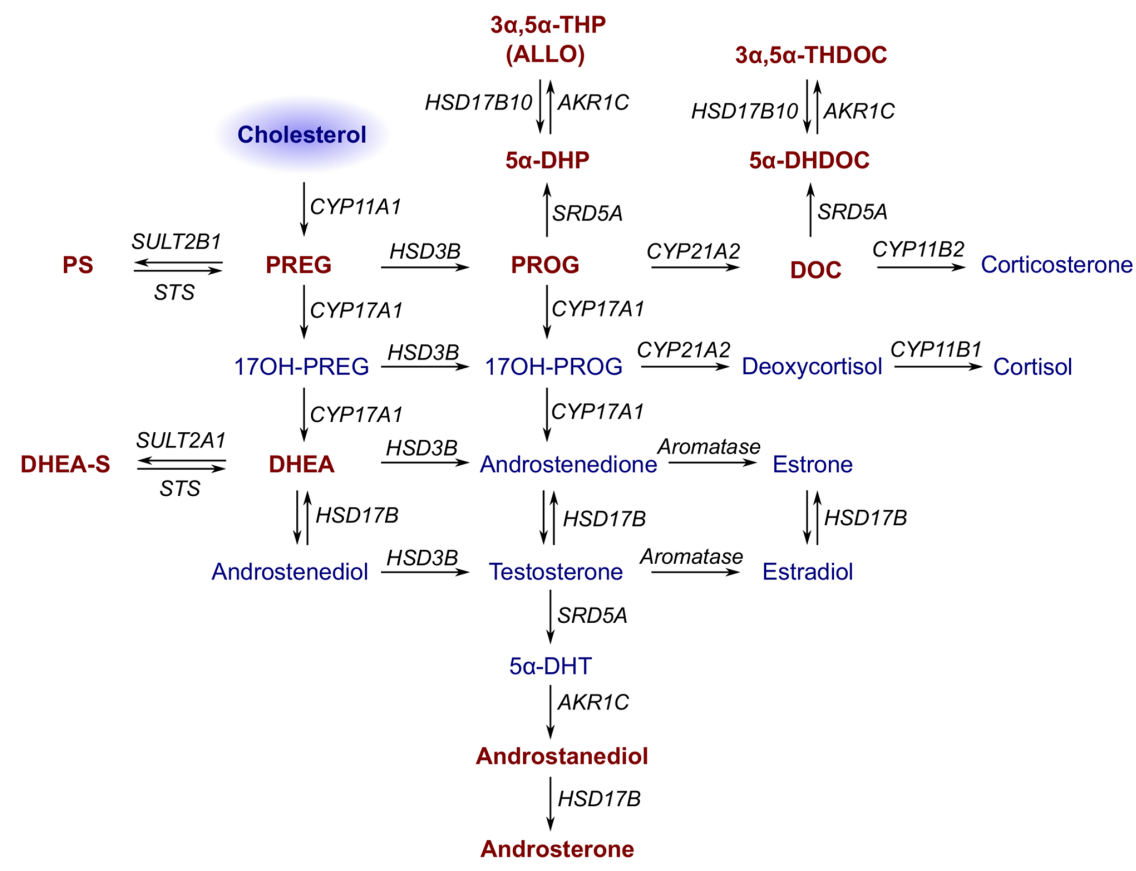

Figure 1

Pathways for neurosteroid synthesis. Steroids: pregnenolone (PREG), pregnenolone sulfate (PS) 17-hydroxypregnenolone (17OH-PREG), dehydroepiandrosterone (DHEA), dehydroepiandrosterone sulfate (DHEA-S); progesterone (PROG), 17-hydroxyprogesterone (17OH-PROG), dihydroprogesterone (DHP), tetrahydroprogesterone (THP), allopregnanolone (ALLO), deoxycorticosterone (DOC), dihydrodeoxycorticosterone (DHDOC), tetrahydrodeoxycorticosterone (THDOC). Broadly studied neurosteroids are in bold-brown. Enzymes: cytochrome P450 side-chain cleavage (CYP11A1), cytochrome P450 11-hydroxylase (CYP11B), hydroxysteroid dehydrogenase (HSD), cytochrome P450 17 $\alpha$-hydroxylase/c17,20-lyase (CYP17A1), steroid sulfatase (STS), sulfotransferase (SULT), steroid $5 \alpha$-reductase (SRD5A), aldo-keto reductase (AKR). 
personality traits, neuronal development, traumatic brain injury and neuroinflammation (Compagnone \& Mellon 2000, Belelli \& Lambert 2005, Charalampopoulos et al. 2008, Lambert et al. 2009).

Several reviews have also described the different enzymatic processes modifying cholesterol and intermediates in the steroidogenic pathway, and the conserved mechanisms in neurosteroid production (Compagnone \& Mellon 2000, Do Rego et al. 2009). Among the different bioconversions, we will focus on the de novo production of neurosteroids, with an emphasis on the very first step leading to this enzymatic cascade, something that has often been used as an indicator of neurosteroid production by cells of the nervous system (Hu et al. 1987a). Enzymatic conversion of cholesterol by a mitochondrial cytochrome P450 side-chain cleavage (P450scc or CYP11A1) to generate PREG is the first and essential step for all steroid synthesis. The P450scc functions as the terminal oxidase in an electron-transfer chain where NADPH donated electrons to adrenodoxin reductase are transferred to adrenodoxin and then to P450scc (Kimura \& Suzuki 1965, Omura etal. 1966, Shikita \& Hall 1973). Overall abundance of P450scc transcripts in the rat brain was estimated to be only $\sim 0.01 \%$ of that measured in the adrenal gland (Mellon \& Deschepper 1993), perhaps indicating that only a small subpopulation of cells are capable of de novo steroidogenesis. Within the different brain regions, P450scc expression was observed in the cortex, basal ganglia, hippocampus, olfactory bulb, hypothalamus, thalamus and cerebellum (Mellon \& Deschepper 1993, Compagnone et al. 1995).

Studies on steroids and their biosynthetic enzymes, mainly based on the adrenals and gonads, have established most of the currently accepted pathways involved in the steroid production (Fig. 1). For the bioconversion of PREG to other neurosteroids, most steroidogenic enzymes that are present in the adrenals and gonads have been identified in the nervous system, as enzymatic activity, presence of transcripts or detection of proteins in different neuronal cells (reviewed in Warner \& Gustafsson 1995, Compagnone \& Mellon 2000, Do Rego et al. 2009). Additional enzymes unique to the nervous system, responsible for bioconversion of peripheral steroids to neurosteroid forms, have also been described (Compagnone \& Mellon 2000). Physiological distribution of this steroid biosynthetic framework in different forms within the nervous system has been demonstrated to be cell type specific with developmental regulation observed in different regions (Compagnone \& Mellon 2000). However, the in vivo complexity in interpreting functional effects based on neurosteroid biosynthetic capability is further confounded by the fact that the enzymes involved can mediate bioconversion of multiple steroid substrates in the pathway. For example, P450c17 mediates both $17-\alpha$ hydroxylase and 17,20-lyase activities (Kominami et al. 1982, Nakajin et al. 1983), on several neuroactive steroid intermediates. Although P450scc knockout/mutations have been phenotyped for steroid deficiency related to the adrenals and gonads in rabbits (Pang et al. 1992) and mice (Hu et al.2002), de novo neurosteroid production and phenotypic deficits resulting from lack of P450scc in the nervous system remain unknown. To this time, there have been no attempts to study the effect of negating de novo neurosteroid production using in vivo genetic models. Therefore, the contribution of de novo steroid synthesis in the nervous system vs effects mediated by peripheral steroid-derived neurosteroids remains to be evaluated.

For de novo steroid production, upstream mechanisms that deliver cholesterol to P450scc have been demonstrated to form the rate-limiting step in PREG synthesis. The proteins and processes involved in this cholesterol delivery is a topic that has been subject to intense investigation in adrenal and gonadal steroidogenic cells for the past 50 years (reviewed in Stocco \& Clark 1996, Stocco 2000, Miller \& Bose 2011, Selvaraj et al. 2015). All functional elements for an identical system for cholesterol transport and de novo steroid production have been demonstrated in specific neuronal tissues (Furukawa et al. 1998).

\section{Mitochondrial cholesterol import}

The P450scc resides on the matrix side of the inner mitochondrial membrane (IMM) in steroid-producing cells (Churchill \& Kimura 1979). Compared with the outer mitochondrial membrane (OMM), the IMM in steroidogenic mitochondria is cholesterol poor (Cheng et al. 1985). To produce steroids, cholesterol needs to be transported from the OMM to the IMM. As cholesterol molecules are highly hydrophobic, they cannot traverse the aqueous intermembrane space (IMS) at a rapid rate (Rennert et al. 1993). Rapid de novo synthesis of a protein was identified to be key for orchestrating cholesterol movement across the IMS (Ferguson 1963). Identification of this putative 'transporter' protein became the focus of research for decades, and the protein, now known as the steroidogenic acute regulatory protein (STAR), was observed in cultured adrenal, Leydig and corpus luteum cells during steroid production (Krueger \& Orme-Johnson 1983, Pon et al. 1986), and was subsequently cloned and sequenced

Published by Bioscientifica Ltd 
(Clark et al. 1994). It was determined that the expression of STAR in steroidogenic cells in the absence of hormone stimulation resulted in an increase in steroid biosynthesis (Clark et al. 1994), highlighting the ratelimiting nature of this step. It was further demonstrated that the expression of StAR in a nonsteroidogenic cell line rendered steroidogenic through transfection of the cholesterol side-chain cleavage system and also resulted in significant increases in steroid production (Lin et al. 1995). Supporting the indispensable role of STAR in steroidogenesis was the demonstration that mutations in the STAR gene were responsible for the potentially fatal lipoid congenital adrenal hyperplasia (lipoid CAH), a disease in which severely afflicted individuals are unable to synthesize steroids (Lin et al. 1995). In corroboration, STAR gene-deleted mice showed a similar inability to synthesize steroids, precisely replicating the human lipoid CAH phenotype (Caron et al. 1997). Crystal structure of the StAR-related lipid transfer (START) domain that was subsequently resolved confirmed the potential of StAR to function as a cholesterol binding and transport protein (Tsujishita \& Hurley 2000).

Before the discovery of STAR, it was observed that chemicals capable of binding to the peripheral benzodiazepine receptor (PBR, the previous name for TSPO), which is present in the OMM (Anholt et al. 1986), could stimulate modest amounts of steroid synthesis in adrenal tumor cells (Mukhin et al. 1989) and Leydig tumor cells (Papadopoulos et al. 1990). Although TSPO was not a product of rapid de novo synthesis during steroid production, it was reported that TSPO knockdown could decrease steroid synthesis (Hauet et al. 2005). As supporting evidence, it was presented that a mono-allelic deletion of Tspo in the constitutively steroidogenic rat R2C Leydig cell line dramatically decreased their ability to produce steroids for a period of time, albeit followed by spontaneous recovery (Papadopoulos et al. 1997b). It was also declared in a review article that the Tspo gene-deleted mice were early embryonic lethal (Papadopoulos et al. 1997a). Examination of TSPO sequence led to discovery of a cholesterol-binding amino acid consensus (CRAC) motif, suggesting that it can bind to cholesterol in the OMM (Li et al. 2001). All these points appeared to make a strong case for TSPO as it was present at the site of mitochondrial import of cholesterol, and its expression was apparent in steroidogenic cells (Papadopoulos 1998). Extrapolating the descriptions, TSPO structure was then modeled as the cholesterol 'channel' (Bernassau et al. 1993, Papadopoulos et al. 1997a,
Rupprecht et al. 2010), with the proposal that STAR delivered cholesterol to the OMM, and TSPO carried out the mitochondrial cholesterol import process. Collectively, these arguments led to the often stated conclusion that TSPO played an indispensable role in steroidogenesis (reviewed in Papadopoulos et al. 1997a, Papadopoulos \& Miller 2012).

Effects observed using TSPO-binding chemicals/ drugs have remained mysterious in that they did not conform to a specific functional pattern (reviewed in Gavish et al. 1999). These included a broad range of observations: cellular respiration, cell proliferation, stress response, apoptosis, reactive oxygen species production, protoporphyrin IX (PPIX) synthesis and steroidogenesis. However, with extant understanding at that period in time, the observations were most often explained as secondary effects resulting from steroid production in cells (Papadopoulos 1998, Papadopoulos \& Lecanu 2009, Rupprecht et al. 2010). Over the ensuing three decades, the concept of steroid production has been used as the basis of interpretation of TSPO function in more than 700 manuscripts across different tissue types.

\section{Dogma refuted: TSPO is not involved in steroidogenesis}

Recent works on TSPO using more definitive genetic in vitro and in vivo models have demonstrated the irreproducibility of earlier results. The use of Tspo-floxed $\left(T_{s p o f / f l}\right)$ mice, to generate Leydig cell-specific TSPO conditional knockout $\left(T s p o^{c \Delta / \Delta}\right)$ mice demonstrated that TSPO was not essential for testosterone production in vivo (Morohaku et al. 2014). Subsequently, global TSPO deletion $\left(\mathrm{Tspo}^{-/-}\right)$in Tspofl/l mice did not affect viability, fertility and the ability to generate steroid hormones ( $\mathrm{Tu}$ et al. 2014). Another group (Banati et al. 2014), independently reproduced this phenotype observed in global $\mathrm{Tspo}^{-/-}$mice, confirming that the nature of the floxed allele or the mouse background were not the criteria affecting this conclusion on viability and steroidogenesis.

These results were also supported by in vitro models, which were previously reported to indicate otherwise. Knockdown of TSPO expression to $>80 \%$ did not affect steroid hormone biosynthesis in Leydig cells (MA-10 and MLTC cells), adrenocortical cells (Y1 cells) (Tu et al. 2014). Complete CRISPR/Cas9-based disruption of TSPO

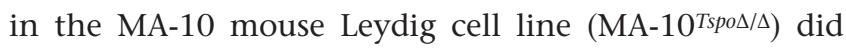
not have any effect on steroidogenesis (Tu et al. 2015).

Published by Bioscientifica Ltd. 
In support, direct examination of mitochondrial cholesterol import in isolated $\mathrm{Tspo}^{-/}$steroidogenic mitochondria did not show any deficits, demonstrating that TSPO is not involved in this process (Banati et al. 2014). Most surprisingly, when the human adrenal H295R cell line was examined, it was determined that it did not express TSPO, but was still competent in making steroids (Tu et al. 2014). All these results were in direct contrast to previous reports in identical model systems (Papadopoulos et al. 1997a,b, Hauet et al. 2005).

Structural features of murine TSPO, as revealed by high-resolution NMR (Jaremko et al. 2014), did not show any indications of a channel-like structure with a hydrophobic core as previously modeled (Bernassau et al. 1993, Papadopoulos et al. 1997a, Rupprecht et al. 2010). The residues considered important for TSPO binding to cholesterol pointed away from the interior of the protein toward the hydrophobic environment of the membrane bilayer (Jaremko et al. 2015b), and did not present any structural basis for cholesterol transport.

Based on these investigations that systematically examined TSPO function in vivo, in vitro and in isolated mitochondria, it could be concluded that TSPO is not involved in mitochondrial cholesterol import for steroidogenesis. As these confirmations are in contrast to what was believed for decades, it also brought the realization that previous statements that appeared in the TSPO literature will require serious reinterpretation. Investigating how the field of steroid endocrinology got to this point, we have carefully reappraised previous studies from 25 years of TSPO research, and examined their limitations that led to the inaccurate association of TSPO and steroidogenesis in a recent review (Selvaraj et al. 2015). Nevertheless, as this proposition of TSPO and mitochondrial cholesterol import had pervaded the scientific literature across multiple fields connected in different organ systems, some have had difficulty in reconciling these differences (Midzak et al. 2015), and others not directly working on mechanisms of steroid production are likewise unable to do so (Campanella 2015, Gatliff \& Campanella 2016). This is mainly because removal of TSPO from the steroid production equation has left the field without an explanation for its high expression in steroidogenic tissues and the different effects mediated by TSPO-binding chemicals/drugs.

Note, a recent manuscript from the research group involved in most of the early studies linking TSPO and steroidogenesis asserted that TSPO is crucial for viability and steroid biosynthesis in an attempt to revive the old model (Fan et al. 2015). Unfortunately, interpretations in this manuscript were seriously flawed (see commentary Selvaraj et al. 2016).

\section{The TSPO paradigm shift: case closed or controversy?}

The burden of proof for overturning popular paragidm is substantial, and to completely understand the new results, we need to examine the historical evidence in perspective, and consider the validity of claims that led to the misconception that TSPO is indispensable for steroidogenesis. For this, we need to dissect literature on adrenal and gonadal steroidogenesis, as these were extrapolated to form the foundation for neurosteroidogensis. It is not our intention to criticize work by other scientists, but we are indeed under obligation to point out some highly cited studies in this field that are not reproducible or have been too loosely interpreted. To make this section palatable for a diverse audience while remaining succinct, we present this information in chronology/relevance with answers, and make every effort to explain the interpretations for each point in our discussion. For a broader discussion on early events, please see our recent review (Selvaraj et al. 2015).

1. Regulation by trophic hormones from the pituitary: In 1985, the first circumstantial evidence presented for TSPO in steroid production was presented: hypophysectomy in rats that resulted in ACTH deficiency could decrease TSPO expression in the adrenal glands (Anholt et al. 1985a). After hypophysectomy, adrenal involution was at a severe stage weighing only $28 \%$ that of control adrenals (Anholt et al. 1985a), suggesting that all proteins associated with the adrenal cortex could decrease. Note that loss of adrenal weight after hypophysectomy is due to shrinkage of the adrenal cortex (Deane \& Greep 1946). However, at that period in time, this possibility was not considered. Subsequent research by this same group documented abundant expression of TSPO in steroidogenic cells of the adrenal and testis (De Souza et al. 1985), and localization to the OMM (Anholt et al. 1986). These observations primed TSPO as a candidate for regulating steroid production.

Answer: A reinvestigation of the basis for the relationship between hypophysectomy and TSPO indicated that after cortical involution, ACTH-induced steroidogenesis was not temporally related to the expression of TSPO (Cavallaro et al. 1993), suggesting that TSPO was not driving the return of corticosterone production.

Published by Bioscientifica Ltd 
However, this early indication that TSPO may not be associated steroid production was overlooked in subsequent studies.

2. TSPO pharmacology: In 1989, testing the effect of TSPO-binding chemicals (including the isoquinolone carboxamide PK11195 and chlorodiazepam Ro5-4864) on the Y1 adrenocortical cell line and the MA-10 Leydig cell line resulted in the induction of progesterone production (Mukhin et al. 1989, Papadopoulos et al. 1990). However, these effects were extremely modest and transient compared with physiological induction (80-fold lower response, and hormone levels plateauing within $40 \mathrm{~min}$ with no progressive accumulation as observed with physiological stimulation of these same cells). Although the effect on cellular physiology was unclear, it was postulated that TSPO played a role in mitochondrial cholesterol import (Krueger \& Papadopoulos 1990).

Answer: Effects of TSPO-binding chemicals were not entirely consistent in other tissues including the nervous system (discussed later in the text) (reviewed in Selvaraj et al. 2015). In 2015, use of the same MA-10 Leydig cells made deficient in TSPO by CRISPR/Cas9-mediated gene targeting indicated that PK11195 could stimulate steroidogenesis even in the absence of TSPO (Tu et al. 2015). This work performed using three independent TSPOdeficient MA-10 cell lines indicated that the transient steroidogenic response mediated by TSPO-binding drugs might be off-target effects. A continued discussion on TSPO pharmacology with respect to neurosteroids is presented in an upcoming section in this review.

3. Role in cholesterol 'translocation': The proposed model for TSPO function (Krueger \& Papadopoulos 1990) did not agree with existing knowledge of the cholesterol import system at that time. As steroidogenesis was sensitive to cycloheximide treatment, it was considered that rapid de novo synthesis of a protein was key for orchestrating this mitochondrial cholesterol import process (Ferguson 1963). However, expression of TSPO did not change with stimulation and hormone production, and transient steroid production by TSPO-binding chemicals was not cycloheximide sensitive (Krueger \& Papadopoulos 1990). Nevertheless, this model was maintained, as no other candidates were identified at that point.

Answer: The STAR was identified as the mediator of mitochondrial cholesterol import that underwent rapid de novo synthesis in steroidogenic cells (Clark et al. 1994). (Please see previous section on mitochondrial cholesterol import). Although TSPO is present in these STAR-deficient mice and humans, it has no compensatory role in the cholesterol transport process. Recent research examining isolated Tspo-deficient steroidogenic mitochondria demonstrated that TSPO does not play a role in mitochondrial cholesterol import (Banati et al. 2014).

4. ACBP/DBI as endogenous ligand: In 1991, TSPO was reported to interact with a protein called the diazepam-binding inhibitor (also known as the Acyl-CoA binding protein/ACBP), which could stimulate steroid production in MA-10 Leydig cells and Y1 adrenocortical cells (Papadopoulos et al. 1991a,b), albeit only at very modest levels similar to TSPO-binding chemicals as described above. Antisense knockdown of ACBP in MA-10 Leydig cells appeared to block steroid biosynthesis demonstrating a vital role for ACBP in steroidogenesis (Boujrad et al. 1993). These reports appeared to provide some credibility in that a putative endogenous 'ligand' for TSPO existed, which could regulate its function in steroidogenic cells.

Answer: ACBP was demonstrated to play a role in maintaining the intracellular Acyl-CoA ester pool size (Mandrup etal. 1993), and synthesis of very long-chain fatty acids and sphingolipids (Gaigg et al. 2001). A spontaneous mutant mouse nm1054, cataloged at the Jackson Laboratory (Ohgami et al. 2005a,b), was subsequently identified to also contain a mutation in the ACBP gene locus (Lee et al. 2007). Loss of ACBP in these nm1054 mice was linked to fatty acid metabolism abnormalities in skin and hair (Lee et al. 2007). The subsequent generation of viable $A c b p$-knockout mice $\left(A c b p^{-/-}\right)$displayed delayed metabolic adaptation to weaning (Neess et al. 2011), and a phenotype of fatty acid metabolic abnormalities in skin and hair similar to nm1054 mutation (Bloksgaard et al. 2012, Neess et al. 2013). There was no phenotypic evidence that indicated defects in steroid hormone production in these $A c b p^{-/-}$mice.

5. Simulated TSPO protein model: In 1993, a 3D model was presented for TSPO depicting its structure as a cholesterol carrier, accommodating a cholesterol molecule within the five alpha helices (Bernassau et al. 1993). This predicted model was used as explanation of the putative function for TSPO in intramitochondrial cholesterol transport.

Answer: Generation of this model was largely shaped by its perceived function in steroidogenesis. The only true prediction in this model was that TSPO potentially contained five transmembrane alpha helices; however, it was imprecise, in that it was calculated to traverse only one

Published by Bioscientifica Ltd 
leaflet of the membrane bilayer (Bernassau et al. 1993), and side-chain orientations were highly speculative. In this structural model, features linking TSPO and cholesterol were assigned based on molecular dynamics simulations congruent with presumed functional requirements. Therefore, permutations and combinations sought for in developing this model were to just satisfy the basis for interpreting TSPO's steroidogenic function.

6. Cholesterol-binding property: In 1998, a cholesterol-binding amino acid consensus motif was characterized at the TSPO C-terminal region (Li \& Papadopoulos 1998). The presence of this motif was initially postulated to indicate the ability of TSPO to bind and translocate cholesterol. Subsequently, it was demonstrated that expression of a HIV TAT-CRAC peptide could potentially compete for cholesterol and inhibit steroidogenesis in the MA-10 Leydig cell line (Li et al. 2001). Deletion of this CRAC motif reduced cholesterol binding when expressed in Escherichia coli (Li \& Papadopoulos 1998). Although these studies offered no experimental evidence that TSPO could transport cholesterol, it was postulated as the mechanism supporting the putative pharmacological steroidogenic response mediated by TSPO.

Answer: The CRAC motif itself is a loose definition; it has previously been pointed out that almost all existing CRAC motifs in proteins (2.7/protein in Streptococcus agalactiae) have no association with cholesterol (Palmer 2004). Most functional CRAC motifs have been described in proteins that associate with cholesterol within the membrane, for example: myelin P0 (Luo et al. 2007) and caveolin-1 (Yang et al. 2014). There exists only biochemical evidence (in nonmembrane environments) that the C-terminal CRAC motif present in TSPO could bind cholesterol. In cells, association of cholesterol to TSPO has been shown to occur in two other distinct locations (Hulce et al. 2013), without any binding at the CRAC motif first described in the C-terminal region (Li \& Papadopoulos 1998). Therefore, despite the strong claims (Li et al. 2001), it remains unclear if the C-terminal CRAC motif can bind cholesterol in cells. Further studies on the newly discovered cholesterol-membrane affinity sites on TSPO could improve understanding of OMM physiology and function.

7. TSPO structure: In 2008, the first experimental evidence for the murine TSPO as a protein with five transmembrane alpha helices was described (Murail et al. 2008). This was followed by a low-resolution structure of Rhodobacter sphaeroides TSPO, constructed using electron cryo-microscopy (Korkhov et al. 2010). These two structures formed the basis of early homology models that were used to speculate that TSPO could form a hydrophobic channel-like interior core lined by the CRAC motif for presumed cholesterol binding and translocation (Papadopoulos et al. 1997a, Rupprecht et al. 2010).

Answer: The key limitation indicated in these early studies is that it is not possible to assign amino acid sequences to low-resolution TSPO structures (Korkhov et al. 2010). A more recent high-resolution NMR structure of TSPO showed that it does not form a 'channel-like' structure and that the side chains of the C-terminal CRAC motif deemed essential for cholesterol binding are located on the outside of the TSPO molecule pointing toward the membrane environment (Jaremko et al. 2014), suggesting that previous models were not accurate. Note: At the time this new structure was published, TSPO was still considered important for steroidogenesis and the authors speculated alternative models for the putative cholesterol translocation; however, no credible structural evidence could be identified as discussed previously (Selvaraj et al. 2015).

8. TSPO knockdown in cells: A study performed in 1998 that examined a stable knockdown of gene expression to decrease TSPO protein levels in clones of MA-10 Leydig cells (Kelly-Hershkovitz et al. 1998) has often been cited to indicate that TSPO was involved in the steroidogenic machinery. Advances in research of STAR mechanism of action resulted in the development of OMM TOM20-STAR fusion constructs that showed maximal hormone production (Bose et al. 2002). This TOM20-STAR construct was subsequently used in conjunction with TSPO knockdown in MA-10 Leydig cells to demonstrate that TSPO was necessary for STAR function in steroidogenesis (Hauet et al. 2005).

Answer: The aforementioned study on TSPO knockdown in MA-10 Leydig cells did not observe differences in acute production of PROG (Kelly-Hershkovitz et al. 1998). They observed that in TSPO antisense 'knockout' cells, PROG levels decreased by about $20 \%$ and only at a late time point $(24 \mathrm{~h})$, leading to an interpretation that TSPO may play a role in PROG metabolism rather than synthesis (Kelly-Hershkovitz et al. 1998). They concluded that 'further studies are needed to confirm the involvement of the 18-kDa PBR subunit in MA-10 Leydig cell steroid biosynthesis' (Kelly-Hershkovitz et al. 1998). This study was perhaps the very first indication that the assumptions underlying TSPO function may be incorrect, but there 
was a key limitation, in that knockdown estimated by PK11195 or Ro5-4864 binding was only at 50\% (KellyHershkovitz et al. 1998). Nevertheless, at that time, this observation was overshadowed by claims to the contrary. Recent examination of TSPO knockdown (>80\%) in MA-10 Leydig cells, MLTC Leydig cells and Y1 adrenocortical cells showed no effects on steroid hormone production (Tu et al. 2014). It was also discovered that the human H295R adrenocortical cell line does not express TSPO, but is still capable of producing steroids (Tu et al. 2014), demonstrating that TSPO is not necessary for STAR function and steroid production.

9. TSPO interaction with STAR: In 2001, visualization to evaluate a TSPO-STAR interaction using fluorescence resonance energy transfer (FRET) suggested that TSPO could interact with StAR in the OMM when coexpressed in nonsteroidogenic Cos-7 cells (West et al. 2001). Together with the above works on TSPO knockdown, the FRET study has been extensively cited to indicate that TSPO is part of the steroidogenic machinery.

Answer: Although this experiment appeared to provide direct evidence that TSPO could interact with STAR, 6 years later, this same research group followed up on their FRET analysis using bioluminescence resonance energy transfer (BRET) and concluded that there was no evidence for TSPO and STAR interaction (Bogan et al. 2007). The BRET analysis utilized cell populations rather than individual cells and three different cell types (CHO cells, MA-10 cells and Cos-7 cells). Also in this report, bacterial and mammalian two-hybrid assays failed to demonstrate a StAR-TSPO interaction (Bogan et al. 2007). The authors concluded that because few cells were selected for FRET analysis in their first report, 'it may have resulted in artifactual data' (Bogan et al. 2007).

10. TSPO deletion in vitro: As genetic evidence for TSPO being an 'indispensable element of the steroidogenic machinery', it was demonstrated that disruption of Tspo in the R2C rat Leydig cell line caused significant adverse morphological changes, lowered proliferation rate and obliterated steroidogenesis (Papadopoulos et al. 1997b). This highly cited manuscript has been used to indicate definitive genetic evidence for the role of TSPO in steroidogenesis, and justify the putative mechanism of action for TSPO ligands.

Answer: R2C Leydig cell line constitutively makes steroids without the need for trophic stimulation, due to the constitutive expression of STAR (Stocco \& Chen 1991, Jo \& Stocco 2004). The aforementioned study on TSPO deletion was based on a solitary distorted clone of R2C Leydig cells selected after homologous recombination. We say distorted because: (1) Disruption of one Tspo allele in the single clone used for this study resulted in a complete disappearance of TSPO protein even though the R2C cells are tetraploid (Papadopoulos et al. 1997b). Subsequent studies have shown that monoallelic deletion of Tspo does not affect TSPO transcript/protein expression (Tu et al. 2014), and complete deletion of Tspo studied in three independent clones of the MA-10 mouse Leydig cell line did not affect morphology, proliferation and/or steroidogenic function (Tu et al. 2015). (2) It was mentioned that proliferation rates of the single R2C clone used in this study spontaneously rebounded after 3 months in culture and hormone production resumed after 2 years in culture without any intervention (Papadopoulos et al. 1997b). Therefore, there are serious limitations to this interpretation, as experimental methods used in this study do not account for R2C cell line clonal effects. There were no attempts to select additional Tspo-disrupted $\mathrm{R} 2 \mathrm{C}$ clones to examine if these results were consistent and specific for TSPO. The previous assumption that $\mathrm{R} 2 \mathrm{C}$ cells may have a higher affinity TSPO ligand binding site (Garnier et al. 1994) was also not accurate. It was subsequently demonstrated that MA-10 cells may have more TSPO molecules and that their affinities are identical to R2C cells (Rao et al. 2002). R2C cells were demonstrated to contain higher levels of the scavenger receptor (SR-B1), hormonesensitive lipase (HSL) and STAR, which may be associated with their constitutive nature of steroid synthesis (Rao et al. 2003). As this effect reported in the Tspo-disrupted R2C Leydig cell clone is not substantiated, and has not been reproducible in the MA-10 Leydig cell line (Tu et al. 2015), it is conceivable that genetic aberrations unrelated to Tspo in this selected R2C clone could have led to this misconception.

11. TSPO deletion in vivo: Another piece of genetic evidence was the report that global $\mathrm{Tspo}^{-/}$mice were early embryonic lethal (Papadopoulos et al. 1997a). This conclusion was presented in a review article without experimental details or phenotypic characterization, but has been highly cited in the literature to indicate an important role for TSPO in development and other basic cellular functions that included steroidogenesis (Papadopoulos et al. 1997a).

Answer: Two independent reports published in 2014 provide solid data on generating and phenotyping global $\mathrm{Tspo}^{-/-}$mice, and demonstrating that TSPO is

Published by Bioscientifica Ltd 
not involved in viability, fertility and steroidogenesis (Banati et al. 2014, Tu et al. 2014). Therefore, we can only speculate that experimental problems hindered the first Tspo knockout attempt.

12. Human TSPO polymorphism: Mutations/ polymorphisms for TSPO were previously sought and excluded in lipoid CAH patients (Lin et al. 1993). However, a common human polymorphism in TSPO (rs6971, leading to amino acid change Ala147Thr) has been demonstrated to cause differences in affinity of TSPO-binding chemicals used for diagnostic imaging (Mizrahi et al. 2012, Owen et al. 2012). Ala147 is considered part of the TSPO PK11195-binding pocket (Jaremko et al. 2014), suggesting that a change to Thr147 could affect binding properties of PK11195 and other chemicals that bind to this region. Functionally, this rs6971 polymorphism was linked to adult separation anxiety in patients with depression (Costa et al. 2009b). This same polymorphism was subsequently associated with decreased PREG production by immune cells in both Thr147 homozygous and heterozygous individuals (Costa et al. 2009a).

Answer: There is no evidence that this TSPO polymorphism suggests a link between TSPO and steroid biosynthesis. PREG production by activated lymphocytes, specifically $\mathrm{T}$ helper 2 cells, has been linked to functional immunosuppression (Mahata et al. 2014). TSPO upregulation has long been associated with immune activation and cellular responses (Liu et al. 2014). Therefore, this polymorphism may indicate an immune function for TSPO associated with its overexpression in inflammatory pathologies, and cannot be considered as evidence for steroidogenesis as suggested previously (Papadopoulos 2014). In contrast to previous views, recent studies have shown that PK11195 affinities are similar between the TSPO and the variant $r s 6971$ polymorphism (Jaremko et al. 2015a, 2016). Moreover, binding affinity was found to have no correlation to putative steroid synthesis mediated by TSPO-binding chemicals (Wolf et al. 2015).

13. TSPO functional redundancy: There has been no mention of functional redundancy in the previous TSPO literature. TSPO knockdown in MA-10 Leydig cells (Hauet et al. 2005) and TSPO monoallelic knockout in R2C Leydig cells (Papadopoulos et al. 1997b) were reported to result in dramatic decreases in steroid hormone production. Nevertheless, after the appearance of results refuting TSPO function, functional redundancy was offered as an explanation in several reviews on this topic (Midzak \& Papadopoulos 2014, Papadopoulos et al. 2015).

Answer: Both the proclaimed studies using TSPO knockdown and 'knockout' Leydig cells, (Papadopoulos et al. 1997b) and (Hauet et al. 2005), have been highly cited as the genetic foundation for justifying research on TSPO pharmacology. Findings that in the same Leydig cells a complete TSPO deletion using CRISPR/Cas9mediated targeting had no effect on steroid hormone production ( $\mathrm{Tu}$ et al. 2015) suggest that this is not a case of functional redundancy, but a core problem with reproducibility, and needs to be considered as such. The TSPO homolog, TSPO2, is expressed almost exclusively in hematopoietic tissues, and does not present a case for functional redundancy in these studies (Fan et al. 2009) (discussed later in this review). If there is indeed a redundant protein or mechanism, it is not clear why these mechanisms did not become apparent in earlier studies that asserted an 'indispensable' role for TSPO in the steroidogenic machinery.

For readers not directly involved in steroidogenesis research, all these points might seem overwhelming, and perhaps hard to decode given the sheer volume of literature based on the fundamental premise that TSPO is linked to steroidogenesis. However, as progress is made with factual data, we believe that clarity for this paradigm shift will start to solidify with advancement of new directions for TSPO research, and oppositions, particularly presented by research groups involved in the early studies on TSPO and steroidogenesis, are addressed by identifying its true physiological function.

\section{TSPO plight not just based on findings in mice}

As indicated in the points above, evidence against TSPO link to steroidogenesis is not only based on studies in Tspo-/- mice. We reiterate this point because several recent reviews have greatly stressed this point and perpetuate the sentiment that evidence in mice is not conclusive, and that there could be compensatory mechanisms (Midzak et al. 2015). In contrast to previous propositions, recent research demonstrates that isolated steroidogenic mitochondria from Tspo-deficient cells do not exhibit any deficits in steroid production (Banati et al. 2014). Also, TSPO knockdown in Y1 adrenocortical cells and MA-10 Leydig cells does not affect steroid hormone production

Published by Bioscientifica Ltd 
(Tu et al. 2014). Convincingly, complete TSPO deletion in MA-10 Leydig cells using the CRISPR/Cas9 system does not affect steroid hormone production (Tu et al. 2015). These new reports, unconnected to work performed on $\mathrm{Tspo}^{-/-}$mice, indicate that previous work on TSPO that used these same cell lines is not reproducible, and therefore challenge the very foundations of the premise that TSPO is involved in steroidogenesis.

As TSPO is considered an important therapeutic target and diagnostic marker for a broad range of inflammatory diseases/disorders (with 24 clinical trials that are either ongoing or recently completed; 17 in the US (source: www.clinicaltrials.gov) and 7 in the EU (source: www.clinicaltrialsregister.eu)), there has been pushback in several forms as these new considerations void its popular mechanism of action. According to this mechanism, TSPO is an essential cholesterol transport protein within the 'mitochondrial transport complex' (Midzak et al. 2011). The problem with this model is that TSPO is the key player, because it is the only cholesterolbinding member that cannot be compensated by STAR function (Hauet et al. 2005). This should mean that deletion of this critical conduit from this complex would offer no opportunity for cholesterol binding and essentially block all steroidogenesis. However, all the recent reports using TSPO-deficient models do not indicate a loss of steroid synthesis.

\section{Neurosteroid production by TSPO-binding drugs}

Based on several studies highlighting the therapeutic value of TSPO in preclinical studies, TSPO is widely popular as a drug target for a variety of diseases/disorders (Papadopoulos \& Lecanu 2009, Rupprecht et al. 2010, Chua et al. 2014, Werry et al. 2015). The primary mechanism of TSPO-binding drugs, at least in the nervous system, is based on their putative ability to stimulate neurosteroid production. While TSPO is not involved in mitochondrial cholesterol import for steroidogenesis, it remains unexplained how different reports have linked the effect of TSPO-binding drugs to neurosteroid production. In steroidogenic cells of the adrenals and testes, TSPO is highly abundant. In contrast, TSPO expression in cells of the nervous system is extremely weak (Daugherty et al. 2013), and it is uncertain if upregulation seen during inflammation/injury approaches the levels seen in steroidogenic cells. Although complete deletion of TSPO from MA-10 Leydig cells did not affect steroid production, it has been demonstrated that supra-physiological overexpression of TSPO in the same MA-10 Leydig cells could increase steroid production (Liu et al. 2006). If we were to use this information for an alternate explanation, it is conceivable that the presence of TSPO in an organelle that is relatively cholesterol poor could increase cholesterol content by potentially enriching cholesterol molecules either through the CRAC motif or through other regions of affinity. As recently speculated (Midzak \& Papadopoulos 2014), it may be possible that drugs that bind TSPO could induce a conformational change resulting in a decreased cholesterol affinity, making more molecules available for steroid synthesis. This mechanism could explain the transient steroidogenic effect observed with different TSPO-binding drugs (Mukhin et al. 1989, Papadopoulos et al. 1990). However, it does not explain how PK11195 could induce steroidogenesis in cells that are deficient in TSPO (Tu et al. 2015), and it is unclear if such a transient production would have physiological and/or therapeutic effect. In this section, we compare existing literature on TSPO-binding drugs and induction of neurosteroids in an attempt to reevaluate the possible mechanisms underlying this connection.

Although the basis of TSPO action through neurosteroid production is indicated as an explanation in numerous studies, only a handful of studies have directly measured neurosteroid synthesis induced by TSPO-binding pharmacological agents (Table 1). Critical comparisons of these studies taking into account the model systems, drug concentrations and the different neurosteroids measured revealed a degree of unexplained inconsistency. In some cases, effects observed were inconsistent even between studies that used the same dose and model system.

The PK11195 action on neurosteroid biosynthesis can be considered equivocal in that the effects range from stimulation to inhibition. Interestingly, PK11195 could block the neurosteroid-inducing effects of other TSPO-binding drugs like FGIN(1-27) (Korneyev et al. 1993), indoleacetamides (Kozikowski et al. 1993), YL-IPA08 (Zhang et al. 2014), CB-34 (Serra et al. 1999) and TTN (Do-Rego et al. 1998). On the other hand, the effect of Ro5-4864 on induction of neurosteroids appears reproducible, albeit with varying potency. Based on thermodynamic studies, even before a link was made between TSPO-binding drugs and steroidogenesis, it was predicted that PK11195 could be a TSPO antagonist, and Ro5-4864 a TSPO agonist (Le Fur et al. 1983). In the same time frame, a study examining TSPO drug effect on audiogenic seizures identified that Ro5-4864 could not only facilitate but also elicit seizures in the

Published by Bioscientifica Ltd. 
Table 1 Studies evaluating neurosteroid production by TSPO-binding drugs.

\begin{tabular}{l} 
Reference \\
\hline PK11195 \\
Korneyev et al. (1993)
\end{tabular}

Korneyev et al. (1993)

Kozikowski et al. (1993)

Kozikowski et al. (1993) Rat brain from rat C6-2B glioma cells

Romeo et al. (1993)

Romeo et al. (1993)

McCauley et al. (1995)

Do-Rego et al. (1998)

Lacor et al. (1999)

Serra et al. (1999)

Serra et al. (1999)

Primofiore et al. (2004) Selleri et al. (2005)

Da Settimo et al. (2008)

Scarf et al. (2012)

Zhang et al. (2014)

do Rego et al. (2015)

Ma et al. (2016)

Santoro et al. (2016)
Isolated mitochondria from rat brain

Adrenalectomized and castrated rats

Isolated mitochondria from rat brain

Frog hypothalamic explants

Rats

In vivo: $3 \mathrm{mg} / \mathrm{kg}$ (IP)

Rats

Rats

Rat C6 glioma cells Rat C6 glioma cells Rat C6 glioma cells Rat C6 glioma cells Rats after the time-dependent sensitization procedure in post-traumatic stress disorder (PTSD) model

Frog hypothalamic In vitro: $30 \mu \mathrm{M}$ explants

Mice injected with lipopolysaccharide (LPS) Rat C6 glioma cells

In vitro: $10 \mathrm{nM}$ to $10 \mu \mathrm{M}$

In vivo: $100 \mu \mathrm{mol} / \mathrm{kg}$ (i.p.)

In vitro: $1 \mu \mathrm{M}$

In vitro: $100 \mu \mathrm{M}$

In vivo: $21,40 \mathrm{mg} / \mathrm{kg}$ (i.p.) (i.p.)

In vitro: $40 \mu \mathrm{M}$

In vitro: $40 \mu \mathrm{M}$

In vitro: $40 \mu \mathrm{M}$

In vitro: $40 \mu \mathrm{M}$
In vitro: $1 \mu \mathrm{M}$

In vivo: $21,40 \mathrm{mg} / \mathrm{kg}$

In vivo: $3 \mathrm{mg} / \mathrm{kg}$ (i.p.)

Neurosteroids measured and drug effects

No effect on PREG. Blocked effect of FGIN(1-27) when combined

No effect on PREG. Blocked effect of indoleacetamides when combined

No effect on PREG.

Blocked effect of

indoleacetamides when

combined

Mitochondria: No effect

on PREG. Slightly $\downarrow$ PREG at $10 \mu \mathrm{M}$

Rat: No effect on PREG in

the forebrain. Blocked

effect of FGIN(1-27)

when combined

$\uparrow$ PREG 7 folds. Most potent among ligands tested.

$\downarrow$ 17OH-PREG, PROG,

17OH-PROG, $5 \alpha$-DHT.

Blocked effect of TTN

when combined

No effect on PREG.

Blocked effect of

Ro5-4864 when

combined

$\uparrow$ PREG, PROG, ALLO,

THDOC in plasma and

cerebral cortex

Pretreatment at dose

$40 \mathrm{mg} / \mathrm{kg}$ blocked effect of CB-34

$\uparrow$ PREG by $48 \%$

$\uparrow$ PREG by $48 \%$

$\uparrow$ PREG by $48 \%$

$\uparrow$ PREG by $37 \%$

No effect on PREG.

Blocked effect of

YL-IPA08 when combined

$\downarrow 17 \mathrm{OH}-\mathrm{PREG}, \mathrm{PROG}$,

DHEA, THP. Blocked

effect of Etifoxine when combined

In vivo: $3 \mathrm{mg} / \mathrm{kg}$ (i.p.)

Prevented LPS-induced reduction in PROG;

$\uparrow$ ALLO in hippocampus. $\uparrow$ PREG by $14 \%$

\section{Inference}

The effect of PK11195 on neurosteroid production was highly inconsistent, ranging from inhibitory, no effect, to stimulatory effects. PK11195 could also antagonize neurosteroidinducing effects of other TSPO binding drugs. Studies have identified different targets for PK11195 that are distinct from TSPO. 
Table 1 (Continued).

\begin{tabular}{|c|c|c|c|c|}
\hline Reference & Model system(s) & Dose & $\begin{array}{l}\text { Neurosteroids measured } \\
\text { and drug effects }\end{array}$ & Inference \\
\hline \multicolumn{5}{|c|}{ Ro5-4864 (4'-chlorodiazepam) } \\
\hline Guarneri et al. (1992) & $\begin{array}{l}\text { Rat C6-2B glioma } \\
\text { cells }\end{array}$ & $\begin{array}{l}\text { In vitro: } 1 \mathrm{nM} \text { to } \\
100 \mathrm{nM}\end{array}$ & $\begin{array}{l}\uparrow \text { PREG production from } \\
\text { mevalonate within } 1 \mathrm{~min}, \\
\max \text { at } 10 \mathrm{nM}(2-3 \text { folds })\end{array}$ & \multirow{12}{*}{$\begin{array}{l}\text { Effect of Ro5-4864 appears } \\
\text { consistent and increases } \\
\text { neurosteroid production, } \\
\text { although the potency } \\
\text { varies between studies. } \\
\text { Ro5-4864 also induced } \\
\text { numerous secondary } \\
\text { effects. Studies have } \\
\text { identified Ro5-4864 effect } \\
\text { as an anxiogenic is through } \\
\text { effects on GABA A receptor. }\end{array}$} \\
\hline Romeo et al. (1992) & $\begin{array}{l}\text { Isolated } \\
\text { mitochondria from } \\
\text { rat C6-2B glioma } \\
\text { cells }\end{array}$ & In vitro: $1 \mathrm{nM}$ to $1 \mu \mathrm{M}$ & $\begin{array}{l}\uparrow \text { PREG } 2 \text { folds at nM } \\
\text { concentrations }\end{array}$ & \\
\hline $\begin{array}{l}\text { Papadopoulos et al. } \\
\text { (1992) }\end{array}$ & $\begin{array}{l}\text { Isolated } \\
\text { mitochondria from } \\
\text { rat C6-2B glioma } \\
\text { cells }\end{array}$ & $\begin{array}{l}\text { In vitro: } 0.1 \mathrm{nM} \text { to } \\
0.1 \mu \mathrm{M}\end{array}$ & $\uparrow$ PREG, max at $100 \mathrm{nM}$ & \\
\hline Korneyev et al. (1993) & $\begin{array}{l}\text { Adrenalectomized } \\
\text { and castrated rats }\end{array}$ & $\begin{array}{l}\text { In vivo: } 6,12, \text { or } \\
18 \mu \mathrm{mol} / \mathrm{kg} \text { (i.v.) }\end{array}$ & $\begin{array}{l}\text { At } 18 \mu \mathrm{mol} / \mathrm{kg}: \uparrow \text { PREG, no } \\
\text { effect in DHEA in } \\
\text { forebrain and cerebellum }\end{array}$ & \\
\hline Romeo et al. (1993) & $\begin{array}{l}\text { Isolated } \\
\text { mitochondria from } \\
\text { rat brain }\end{array}$ & $\begin{array}{l}\text { In vitro: } 10 \mathrm{nM} \text { to } \\
10 \mu \mathrm{M}\end{array}$ & $\begin{array}{l}\uparrow \text { PREG accumulation, max } \\
\text { at } 10 \mu \mathrm{M} \text { ( } 6-7 \text { folds). } \\
\text { Most potent among } \\
\text { ligands tested }\end{array}$ & \\
\hline McCauley et al. (1995) & $\begin{array}{l}\text { Isolated } \\
\text { mitochondria from } \\
\text { rat brain }\end{array}$ & In vitro: $1 \mu \mathrm{M}$ & $\uparrow$ PREG (3 folds) & \\
\hline Do-Rego et al. (1998) & $\begin{array}{l}\text { Frog hypothalamic } \\
\text { explants }\end{array}$ & In vitro: $1 \mu \mathrm{M}$ & $\begin{array}{l}\uparrow \text { conversion of PREG into } \\
17 \mathrm{OH}-\mathrm{PREG}, \mathrm{PROG}, \\
17 \mathrm{OH}-\mathrm{PROG}, 5 \alpha-\mathrm{DHT}, \\
\text { steroid } \mathrm{X}\end{array}$ & \\
\hline Lacor et al. (1999) & Rats & In vivo: 3 mg/kg (i.p.) & $\begin{array}{l}\uparrow \text { PREG in plasma and } \\
\text { sciatic nerve }\end{array}$ & \\
\hline Primofiore et al. (2004) & Rat C6 glioma cells & In vitro: $40 \mu \mathrm{M}$ & $\uparrow$ PREG $41 \%$ & \\
\hline Selleri et al. (2005) & Rat C6 glioma cells & In vitro: $40 \mu \mathrm{M}$ & $\uparrow$ PREG $41 \%$ & \\
\hline Da Settimo et al. (2008) & Rat C6 glioma cells & In vitro: $40 \mu \mathrm{M}$ & $\uparrow$ PREG $41 \%$ & \\
\hline \multicolumn{4}{|l|}{ Diazepam } & \\
\hline McCauley et al. (1995) & $\begin{array}{l}\text { Isolated } \\
\text { mitochondria from } \\
\text { rat brain }\end{array}$ & In vitro: $1 \mu \mathrm{M}$ & $\uparrow$ PREG 1.7 fold & \multirow[t]{3}{*}{$\begin{array}{l}\text { Effect of Diazepam is weak, } \\
\text { but primary effect is } \\
\text { through } \mathrm{GABA}_{\mathrm{A}} \text { receptors. }\end{array}$} \\
\hline Wolf et al. (2015) & $\begin{array}{l}\text { Mouse BV2 } \\
\text { microglia cells }\end{array}$ & In vitro:0.1-10 $\mu \mathrm{M}$ & BV2 cells:no effect & \\
\hline Wolf et al. (2015) & Rat C6 glioma cells & In vitro: $0.1-10 \mu \mathrm{M}$ & $\begin{array}{l}\text { C6 cells: very mildly } \\
\uparrow \text { PREG at } 1,10 \mu \mathrm{M}\end{array}$ & \\
\hline \multicolumn{5}{|c|}{ DBI and its fragments TTN: DBI (17-50), ODN: DBI (33-50) } \\
\hline Romeo et al. (1992) & $\begin{array}{l}\text { Isolated } \\
\text { mitochondria from } \\
\text { rat C6-2B glioma } \\
\text { cells }\end{array}$ & $\begin{array}{l}\text { In vitro: } 1 \mathrm{nM} \text { to } 1 \mu \mathrm{M} \\
\mathrm{DBI}\end{array}$ & $\begin{array}{l}\uparrow \text { PREG } 2 \text { folds at nM } \\
\text { concentrations }\end{array}$ & \multirow{4}{*}{$\begin{array}{l}\text { Effects are not consistent: } \\
\text { TTN and ODN are reported } \\
\text { to either increase or have } \\
\text { no effect on neurosteroid } \\
\text { production. In frog } \\
\text { hypothalamic explants, the } \\
\text { same group arrived at } \\
\text { conflicting conclusions } \\
\text { about TTN effect on DHEA } \\
\text { and PROG. }\end{array}$} \\
\hline $\begin{array}{l}\text { Papadopoulos et al. } \\
\text { (1992) }\end{array}$ & $\begin{array}{l}\text { Isolated } \\
\text { mitochondria from } \\
\text { rat C6-2B glioma } \\
\text { cells }\end{array}$ & $\begin{array}{l}\text { In vitro: } 0.1 \mathrm{nM} \text { to } \\
0.1 \mu \mathrm{M} \mathrm{DBI} \text { or TTN }\end{array}$ & $\begin{array}{l}\text { DBI, TTN: } \uparrow \text { PREG, max at } \\
5-10 \text { nM (2-3 folds) }\end{array}$ & \\
\hline $\begin{array}{l}\text { Papadopoulos et al. } \\
\text { (1992) }\end{array}$ & $\begin{array}{l}\text { Isolated } \\
\text { mitochondria from } \\
\text { rat C6-2B glioma } \\
\text { cells }\end{array}$ & $\begin{array}{l}\text { In vitro: } 0.1 \mathrm{nM} \text { to } \\
0.1 \mu \mathrm{M} \text { ODN }\end{array}$ & ODN: no effect on PREG & \\
\hline McCauley et al. (1995) & $\begin{array}{l}\text { Isolated } \\
\text { mitochondria from } \\
\text { rat brain }\end{array}$ & $\begin{array}{l}\text { In vitro: } 1 \mu \mathrm{M} \text { ODN or } \\
\mathrm{DBI}(42-50)\end{array}$ & $\begin{array}{l}\text { ODN, DBI(42-50): } \uparrow \text { PREG } \\
\text { (<2 folds) }\end{array}$ & \\
\hline
\end{tabular}


Table 1 (Continued).

Reference
McCauley et al. (1995)

Do-Rego et al. (1998)

do Rego et al. (2015)

do Rego et al. (2015)

Etifoxine (Stresam)

Verleye et al. (2005)

Verleye et al. (2005)

do Rego et al. (2015)

do Rego et al. (2015)

Wolf et al. (2015)

Wolf et al. (2015)

Ravikumar et al. (2016)

Ravikumar et al. (2016)

Rat primary

FGIN(1-27) and other indoleacetamides Romeo et al. (1992)

Korneyev et al. (1993) homogenates

Frog hypothalamic astrocytes

Isolated mitochondria from rat C6-2B glioma cells

Frog hypothalamic In vitro: $30 \mathrm{nM}$ TTN explants (where membrane receptor signaling is disrupted)

Frog hypothalamic (where membrane receptor signaling is disrupted)

Rats

Adrenalectomized and castrated

(ADX-CX) rats explants (where membrane receptor signaling is disrupted) homogenates (where membrane receptor signaling is disrupted)

Mouse BV2 microglia cells

Rat C6 glioma cells

Rat C6 glioma cells

Adrenalectomized and castrated rats

In vitro: $30 \mathrm{nM}$ TTN

In vitro: $0.3-30 \mu \mathrm{M}$

In vitro: $0.3-30 \mu \mathrm{M}$

In vitro: $0.1-10 \mu \mathrm{M}$

In vitro: $12.5,25$, $50 \mu \mathrm{M}$

Dose
In vitro: $1 \mu \mathrm{M}$ TTN or
TTN+ODN
In vitro: $1 \mathrm{nM}$ to $1 \mu \mathrm{M}$
TTN

Neurosteroids measured and drug effects

Inference

TTN or TTN+ODN: no

effect on PREG

$\uparrow 170 H-P R E G$,

17OH-PROG, $5 \alpha$-DHT,

steroid $\mathrm{X}$ in a dose-

dependent manner; no

effect on DHEA and

PROG

Explant: $\uparrow 170 \mathrm{H}-\mathrm{PREG}$,

DHEA, PROG, THP. Had

synergistic effect with

Etifoxine to $\uparrow$ hormones

Homogenates: No effect on 17OH-PREG, DHEA, PROG, DHP, THP

In vivo: $50 \mathrm{mg} / \mathrm{kg}$ (i.p.) Rats: $\uparrow$ PREG, PROG, 5a-DHP, ALLO but not corticosterone in brain and plasma

In vivo: $50 \mathrm{mg} / \mathrm{kg}$ (i.p.) $A D X-C X$ rats: $\uparrow$ PREG, PROG, ALLO in brain to a lesser extent Explant: $\uparrow 170 \mathrm{H}-\mathrm{PREG}$, DHEA, PROG, DHP, THP. $\downarrow$ DHP at $>1 \mu \mathrm{M}$. Effect was not blocked by PK11195 or Flumazenil

Homogenates (no membrane receptors): Still $\uparrow 170$ H-PREG, DHEA PROG, THP but $\downarrow$ DHP

BV2 cells: $\uparrow$ PREG in a dose-dependent manner, but $\downarrow$ PREG at $10 \mu \mathrm{M}$

In vitro: $0.1-10 \mu \mathrm{M} \quad$ C6 cells: $\uparrow$ PREG in a dose-dependent manner

Cells: $\uparrow$ PREG in a dosedependent manner

In vivo: $50 \mathrm{mg} / \mathrm{kg}$ (i.p.) Rat brain: No effect on all neurosteroids tested (PREG, PROG, ALLO, DHP, THP)

In vitro: $1 \mathrm{nM}$ to $1 \mu \mathrm{M} \quad \uparrow$ PREG 2 folds at $\mathrm{nM}$ concentrations

In vivo: $7 \mu \mathrm{mol} / \mathrm{kg}$ (i.v.) FGIN (all doses except or $200,400, \quad 200 \mu \mathrm{mol} / \mathrm{kg}): \uparrow$ PREG, no $800 \mu \mathrm{mol} / \mathrm{kg}$ (p.o.) effect in DHEA in forebrain and cerebellum
Effects reported for

Etifoxine are not consistent: an increase in neurosteroid production was observed in some studies, without effects in others.

Neurosteroid induction by Etifoxine was suggested to be the most potent in one study, although its binding affinity for TSPO is lowest among the compounds tested.

Etifoxine could stimulate neurosteroid production even in the absence of TSPO and other membrane receptors.

FGIN(1-27) and some other indoleacetamides showed increases in neurosteroid production. http://joe.endocrinology-journals.org DOI: 10.1530/JOE-16-0241
C) 2016 Society for Endocrinology Printed in Great Britain
Published by Bioscientifica Ltd. 
Table 1 (Continued).

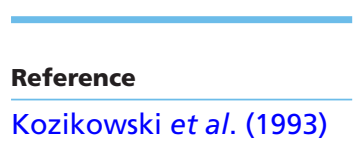

Kozikowski et al. (1993)

Romeo et al. (1993)

Romeo et al. (1993)

Bitran et al. (2000)

Petralia and Frye (2005) Rats

\section{XBD-173 (AC-5216, Emapunil)}

Wolf et al. (2015)

Wolf et al. (2015)

Ravikumar et al. (2016)

Ravikumar et al. (2016)

Mitsui et al. (2015)

\section{Mouse BV2 \\ microglia cells \\ Rat C6 glioma cells \\ Rat C6 glioma cells \\ Rat primary astrocytes}

Rats exposed to restraint stress
Dose

Different

indoleacetamides

in vitro: $1 \mu \mathrm{M}$

Different

indoleacetamides

in vitro: $1 \mu \mathrm{M}$

In vitro: $10 \mathrm{nM}$ to

$10 \mu \mathrm{M}$

In vivo: $800 \mu \mathrm{mol} / \mathrm{kg}$

(p.o.)

In vivo: $2.5 \mu \mathrm{g}$ (intrahippocampal injections)

In vivo: $5 \mu \mathrm{g}$ (intracranial into ventral tegmental area)

In vitro: $0.1-10 \mu \mathrm{M}$

In vitro: $0.1-10 \mu \mathrm{M}$

In vitro: $12.5,25$, $50 \mu \mathrm{M}$ In vivo: $50 \mathrm{mg} / \mathrm{kg}$ (i.p.)

In vivo: $0.1,1$, $10 \mathrm{mg} / \mathrm{kg}$ (p.o.)
Neurosteroids measured and drug effects

A subset of compounds

$\uparrow$ PREG in mitochondria

A subset of compounds

$\uparrow$ PREG in mitochondria

Mitochondria: $\uparrow$ PREG accumulation, max at $10 \mu \mathrm{M}$ (5-6 folds)

Rat: $\uparrow$ PREG 2.3 folds in the forebrain

$\uparrow$ ALLO in both hippocampus and plasma

$\uparrow$ ALLO 2 folds in the midbrain

BV2 cells: Mildly $\uparrow$ PREG

C6 cells: Mildly $\uparrow$ PREG only at $10 \mu \mathrm{M}$

Cells: $\uparrow$ PREG in a dosedependent manner Rat brain: $\uparrow$ PREG, PROG, $5 \alpha$-DHP, ALLO, $3 \beta 5 \alpha-$ THP, $5 \alpha 20 \alpha-$ THP

Blocked stress-induced increase in PREG, PROG, ALLO, THDOC in hippocampus

PIGAs (N,N-dialkyl-2-phenylindol-3-ylglyoxylamides) MPIGA (N,N-di-n-propyl-2-(4-methylphenyl)indol-3-ylglyoxylamide)

Primofiore et al. (2004)

Rat C6 glioma cells

In vitro: $40 \mu \mathrm{M}$ PIGAs

Selected compounds $\uparrow$ PREG by $40-166 \%$ while others had no effects on PREG

Da Settimo et al. (2008) Rat C6 glioma cells In vitro: $40 \mu \mathrm{M}$ PIGAs

Costa et al. (2011)

Human astrocytoma

In vitro: $100 \mathrm{nM}$ to ADF cells $100 \mu \mathrm{M}$ MPIGA

Costa et al. (2011)

Human astrocytoma ADF cells

In vitro: $100 \mathrm{nM}$ to $100 \mu \mathrm{M}$ MPIGA

Santoro et al. (2016)

Some compounds $\uparrow$ PREG $60-171 \%$ while others had no effects on PREG $\uparrow$ PREG to $177 \%$ only at $40 \mu \mathrm{M}$; $\downarrow$ PREG to $50 \%$ at $100 \mu \mathrm{M}$

$\uparrow$ PROG to $167 \%$, $\uparrow$ ALLO

to $115 \%$ at $40 \mu \mathrm{M}$.

$\uparrow$ PREG by $97 \%$
Effect of XBD-173 was stimulatory toward neurosteroid production. However, XBD-173 was not efficacious in EAE mouse model, and in the human clinical trial as an anxiolytic.

Effect of ONO-2952 was only tested using a stress model and observations could be subject to secondary effects. Results showed attenuated effects on neurosteroid production.

Selected compounds in this group could increase neurosteroid production but only at high concentrations. A few compounds that had high affinity for TSPO showed mild to no effect. 
Table 1 (Continued).

$\begin{array}{ll}\text { Reference } & \\ \begin{array}{l}\text { Imidazopyridine- and Pyrazolopyrimidine- } \\ \text { Serra et al. (1999) }\end{array} & \begin{array}{l}\text { Model system(s) } \\ \text { Rats }\end{array} \\ \text { Serra et al. (1999) } & \begin{array}{l}\text { Adrenalectomized } \\ \text { and } \\ \text { orchidectomized } \\ \text { (ADX-ORX) rats }\end{array} \\ \text { Trapani et al. (1999) } & \text { Rats }\end{array}$

Trapani et al. (2005) Rats

Dose
In vivo: $3-50 \mathrm{mg} / \mathrm{kg}$
(i.p.) CB-34, CB-50 or
CB-54

In vivo: $3-50 \mathrm{mg} / \mathrm{kg}$ (i.p.) $\mathrm{CB}-34$ Rats

In vivo: $25 \mathrm{mg} / \mathrm{kg}$ (i.p.) 2-phenylimidazo $[1,2-\alpha]$ pyridineacetamides

Neurosteroids measured and drug effects

$\uparrow$ PREG, PROG, ALLO, THDOC in plasma, brain of normal rats in a dose-dependent manner CB-34 at $25 \mathrm{mg} / \mathrm{kg} \uparrow$ PREG, PROG, ALLO in ADX-ORX rats to a lesser extent

Trapani et al. (1999)

Rats after the time-dependent sensitization procedure in post-traumatic stress disorder (PTSD) model

Selleri et al. (2005) Rat C6 glioma cells

Pyrrolobenzoxazepines

Scarf et al. (2012)

Rat C6 glioma cells

In vitro: $40 \mu \mathrm{M}$

In vitro: $40 \mu \mathrm{M} 2-$ arylpyrazolo[1,5-a] pyrimidin-3-yl acetamides

In vivo: $0.3 \mathrm{mg} / \mathrm{kg}$ (p.o.) YL-IPA08

.)

Selected compounds $\uparrow$

PREG, PROG, ALLO,

THDOC in cerebral cortex and plasma, $\uparrow$ corticosterone in plasma. Some had mild or no effect

In vivo: $25 \mathrm{mg} / \mathrm{kg}$ (i.p.) Selected compounds $\uparrow$ 2-phenylimidazo pyridineacetamides PROG, 3 $\alpha, 5 \alpha-$ THPROG, $3 \alpha, 5 \alpha-$ THDOC in cerebral cortex and plasma. One compound with subnanomolar affinity for TSPO showed mild effect

$\uparrow$ ALLO in prefrontal cortex and serum
Pyridazinoindole (SSR180575)

Ferzaz et al. (2002) Rats

PPIX

Romeo et al. (1992)
Isolated mitochondria from rat C6-2B glioma cells
In vivo: $3 \mathrm{mg} / \mathrm{kg}$ (i.p.) $\uparrow$ PREG in brain, sciatic

In vitro: $1 \mathrm{nM}$ to $1 \mu \mathrm{M} \quad$ No effect on PREG even at $1 \mu \mathrm{M}$

\section{Inference}

A subset of compounds in this group that had high affinity for TSPO could stimulate synthesis of neurosteroids, whereas another subset also with high affinity was without effects. nerve ( 2 folds) but not in plasma

2 compounds $\uparrow$ PREG $70-90 \%$, one had no effects on PREG

Some compounds $\uparrow$ PREG while others with high binding affinity to TSPO did not
This study demonstrated that neurosteroid production is not correlated to binding affinity of drugs to TSPO.

Effect of SSR 180575 showed increase neurosteroid production, but not peripheral steroids.

Effect of PPIX, considered an endogenous ligand with nanomolar affinity for TSPO showed no effect on neurosteroid production.
๑) 2016 Society for Endocrinology Printed in Great Britain 
absence of noise stimuli (Benavides et al. 1984). Despite the proposed specificity to TSPO, the effects of Ro5-4864 were also suggested to act via directly perturbing the $\mathrm{GABA}_{\mathrm{A}}$ receptor chloride ionophore complex (Weissman et al. 1984). The observation that Ro5-4864 was anxiogenic (File \& Lister 1983) was also the case for PK11195 when provided at a higher dose (File \& Pellow 1985). Therefore, discussions regarding the specificity of these compounds emerged even before putative effects for TSPO on steroid synthesis were proposed. Binding of PK11195 to other targets in the cell have been described: the ATP-binding cassette (ABC) transporters (Walter et al. 2005), constitutive androstane receptor (CAR) (Li et al. 2008, Anderson et al. 2011), pregnane $X$ receptor (Anderson et al. 2011), oncoprotein B cell lymphoma 2 (Bcl-2) (Gonzalez-Polo et al. 2005) and the $\mathrm{F}_{1} \mathrm{~F}_{0}$ ATP synthase (Seneviratne et al. 2012), all of which could confound the TSPO-mediated effect. Moreover, changes to membrane properties as a result of direct incorporation of PK11195 into the lipid bilayer have been suggested to contribute to TSPO-independent effects (Hatty et al. 2014).

Examination of neurosteroid production with diazepam that can bind to both $\mathrm{GABA}_{\mathrm{A}}$ receptor and TSPO has only been conducted using in vitro models with mild effects on neurosteroids observed (McCauley et al. 1995, Wolf et al. 2015). Effects of diazepam on TSPO are hard to delineate due to robust actions on GABAergic synaptic transmission. Results for etifoxine, commercially sold as an anxiolytic and anticonvulsant (Stresam), have been mixed. Etifoxine was demonstrated to be the most potent inducer of neurosteroid production in vitro, despite its lower binding affinity (Wolf et al. 2015). In vivo results have been conflicting, with contrasting results in the same rat model and dose showing induction (Verleye et al. 2005) or no effect (Ravikumar et al. 2016). Recent studies also indicate that induction of neurosteroids by etifoxine could occur independent of membrane receptors including TSPO (do Rego et al. 2015). Although there is literature correlating the anxiolytic effect of etifoxine and neurosteroid production (Ugale et al. 2007), early studies on etifoxine have indicated that it interacts with the chloride channel coupled to the $\mathrm{GABA}_{\mathrm{A}}$ receptor (Verleye et al. 1999), and can directly modulate GABAergic synaptic transmission (Schlichter et al. 2000). Moreover, in vivo effects for etifoxine that are anxiolytic in contrast to Ro5-4864 that appears anxiogenic indicate that interpretations of its mechanism of action may not be straightforward.
Reports for FGIN(1-27) and other indolacetamides demonstrate increases in varying subsets of neurosteroids. It must be noted that FGIN(1-27) was also investigated as an agent for inducing apoptosis in cancer cells by inducing oxidative stress (Maaser et al. 2001, 2005, Sutter et al. 2002, 2005). This distinct direction of FGIN(1-27) action introduces another layer of difficulty in interpreting a pharmacological relationship with TSPO.

The drug XBD173 (Emapunil) has been a topic of intense investigation for use as an anxiolytic (Kita et al. 2004). Optimistic outcomes were reported using a high dose of XBD173 in an induced model of panic disorder in rats (Rupprecht et al. 2009). Although neurosteroid production was proposed as a mechanism, it was not tested. Novartis Pharmaceuticals subsequently launched a human clinical trial (NCT00108836) for evaluating XBD173 efficacy in patients with generalized anxiety disorders. Although results from this trial were not published, it was reported that XBD173 treatment showed no reduction compared with placebo in a variety of anxiety measures. Although this failure was attributed to XBD173-binding affinity and the human TSPO polymorphism (A147T) (Owen et al. 2011), it remains merely a hypothetical proposition for drug efficacy (Wolf et al. 2015). Subsequently, XBD173 was removed from the drug development pipeline. Recent studies have shown moderate increases in neurosteroid production with XBD173 both in vitro and in vivo (Wolf et al. 2015, Ravikumar et al. 2016). Despite this neurosteroid effect, in rodent experimental autoimmune encephalitis (EAE) models, XBD173 was not efficacious (Ravikumar et al. 2016). As part of the same study, animals in a group that received etifoxine showed ameliorated EAE clinical signs, but etifoxine in vivo had no effect on neurosteroid production (Ravikumar et al. 2016).

Effect of ONO-2952 has been examined only in the context of a stress model (Mitsui et al. 2015). Only selected compounds of PIGAs, imidazopyridine acetamides, pyrazolopyridine acetamides and pyrrolobenzoxepines demonstrated a link to neurosteroid production, whereas some with high binding affinity to TSPO showed no effect on neurosteroidogenesis. Interestingly, for PPIX that is considered a high-affinity endogenous ligand, there are very few studies examining steroid production. PPIX could competitively displace PK11195 (Wendler et al. 2003) and PBR28 (Ozaki et al. 2010), suggesting that it binds to the same site on TSPO. In perhaps the only study testing this endogenous ligand, no steroidogenic effect was observed as a result of PPIX binding to TSPO (Romeo et al. 1992).

Published by Bioscientifica Ltd. 
Previously identified as a ligand for the $\mathrm{GABA}_{\mathrm{A}}$ receptor (Gray et al. 1986), DBI/ACBP was also observed to interact with TSPO (Garnier et al. 1994). Of the two ACBP-processed peptides (termed endozepines), triakontatetraneuropeptide (TTN; DBI(17-50)) and octadecaneuropeptide (ODN; DBI(33-50)), TTN could stimulate dose-dependent mitochondrial steroid synthesis similar to ACBP (Papadopoulos et al. 1991b). Examination of DBI and TTN in neuronal in vitro models also revealed mild to no effects with some inconsistencies. As described previously, ACBP function is linked to lipid metabolism (Mandrup et al. 1993, Gaigg et al. 2001). These observations were confirmed in ACBP-knockout mice that indicate no role in steroid synthesis (Neess et al. 2011, 2013, Bloksgaard et al. 2012). Moreover, studies by independent groups could not confirm the TSPO-DBI interaction (Bogan et al. 2007). In the long history of steroidogenesis research, there have been similar positive results using peptides that stimulated steroids through nonspecific mechanisms. A peptide termed the 'steroidogenesis activator peptide' (SAP) was initially linked to acute stimulation of steroid synthesis (Pedersen \& Brownie 1983, 1987). However, subsequent studies demonstrated that the SAP was part of the glucose-regulated protein 78 (GRP78), with no involvement in steroidogenesis (Luo et al. 2006, Wang et al. 2009, Wisniewska et al. 2010, Wey et al. 2012).

There are some core problems with pharmacological approaches for targeting TSPO in vivo. (1) Effects of TSPObinding drugs on systemic functions are not considered in neurosteroid studies. The use of ${ }^{11} \mathrm{C}$-XBD173 identified high accumulation in the lungs, heart, adrenal glands and other organs rich in TSPO; accumulation observed in the CNS is relatively much lower (Zhang et al. 2007). Drug effects in these peripheral tissues/organs that express high levels of TSPO that could be more robust and distinct from nervous system responses are almost always ignored. (2) Physiological stimulation of steroid synthesis would involve factors beyond the mitochondrial cholesterol import mechanism. Thereneeds to beconcurrentactivation of cholesterol uptake and synthesis, and activation of delivery systems that can move free cholesterol to the OMM. There is no evidence that TSPO-binding drugs are capable of activating these pathways. Moreover, there is also no correlation between the levels of TSPO expression and neurosteroid production capability within different regions of the brain. In support, some studies using in vivo models indicate that despite neurosteroid induction in the CNS, TSPO-binding drugs failed to induce steroid synthesis in high TSPO-expressing organs like the adrenal (Romeo et al. 1993, Ferzaz et al. 2002, Verleye et al. 2005). Therefore, the assumption that targeting TSPO could result in a robust cellular steroidogenic response might be a too simplistic view. One plausible explanation for neurosteroid production could be that induction of a form of cellular/organismal stress by these drugs could trigger a secondary steroidogenic response in the CNS unrelated to TSPO expression levels or TSPO function.

Despite the inconsistencies, lack of specificity and other confounding factors, pharmacological activation of TSPO and neurosteroid production continues to be extensively cited in the literature. Based on genetic studies, there is strong indication that the effects observed could be nonspecific or secondary responses unrelated to direct involvement of TSPO (Tu et al. 2015). Therefore, it is extremely important to reassess the physiological relevance of these pharmacological studies using genetic models that lack TSPO to delineate TSPOmediated actions from off-target and secondary effects.

\section{TSPO is not part of the mitochondrial permeability transition pore}

Distinct from the purported role for TSPO in steroidogenesis, it was also thought that TSPO might play a role in the mitochondria-mediated cell death process called the mitochondrial permeability transition (MPT). The MPT refers to the opening of a nonspecific pore that permits any molecule $<1.5 \mathrm{kDa}$ through the inner mitochondrial membrane allowing equilibration of the mitochondrial matrix and the cytosol leading to loss of mitochondrial function and cell death (Haworth \& Hunter 1979, Hunter \& Haworth 1979a,b). Effects observed using TSPO-binding drugs (Kinnally et al. 1993) and copurification of TSPO with other proteins thought to be involved in MPT (McEnery et al. 1992), initially linked TSPO to this process. However, through development of conditional Tspo ${ }^{c \Delta / \Delta}$ genetic models, it was recently demonstrated that TSPO plays no role in the regulation or structure of the MPT pore (Sileikyte et al. 2014). This was another surprising discovery because distinct from steroid synthesis, the validity of a potential alternate mechanism that linked TSPO and TSPO-binding drug action to a number of different neuropathologies was challenged. In order to keep this manuscript focused on neurosteroid production, we are not reviewing the different aspects of MPT regulation 
affected by this conclusion. Implications from this recent understanding of TSPO and advances toward explaining the MPT process have been critically assessed elsewhere (see review Bernardi et al. 2015).

\section{Is TSPO2 an isofunctional or heterofunctional homolog?}

Due to Tspo sequence conservation from bacteria to humans, there has been some interest in studying the functional evolution of this gene (Fan et al. 2012). TSPO2 (PBRL/Peripheral benzodiazepam-like) was identified as a gene that emerged from a duplication event preceding speciation of reptiles, birds and mammals (Nakazawa et al. 2009). Unlike TSPO expression that is observed at high levels in cells active in lipid storage/metabolism (Fig. 2), TSPO2 expression appears restricted to the bone marrow (Fan et al. 2009, Nakazawa et al. 2009), and has not been detected in steroidogenic tissues (confirmed in Morohaku et al. 2014, Tu et al. 2014). Subcellular localization of TSPO2 using specific antibodies has not been performed; localization based on overexpression studies using C-terminal GFP/DsRed-TSPO2 fusion proteins (chicken, mouse and human) in cell lines have led to conflicting proposals. The group who studied chicken TSPO2 demonstrated mitochondrial localization (Nakazawa et al. 2009), and the group who studied mouse and human TSPO2 proposed that TSPO2 is localized to the endoplasmic reticulum and the nuclear membrane (Fan et al. 2009). These studies have demonstrated functional disparities as well. Based on the study in the chicken, a strict coregulation of Tspo2 expression but not Tspo expression with genes involved in hematopoiesis was demonstrated (Nakazawa et al. 2009). This led to the conclusion that TSPO2 may be involved in heme availability for the assembly of hemoglobin (Nakazawa et al. 2009). In contrast, the study with mouse and human TSPO2 was an extrapolation of previous work on TSPO and steroidogenesis from the same authors, and suggested that TSPO2 is involved in cholesterol uptake and trafficking in erythroid cell types (Fan et al. 2009). At the present time, there are no gene-knockout models to study loss-of-function resulting from TSPO2 deletion, and understanding of its function remains rudimentary. Nevertheless, what we do know is that distinct tissue localization patterns and regulation between TSPO and TSPO2 negates concerns of potential functional redundancy in studies that use Tspo gene-deleted models.

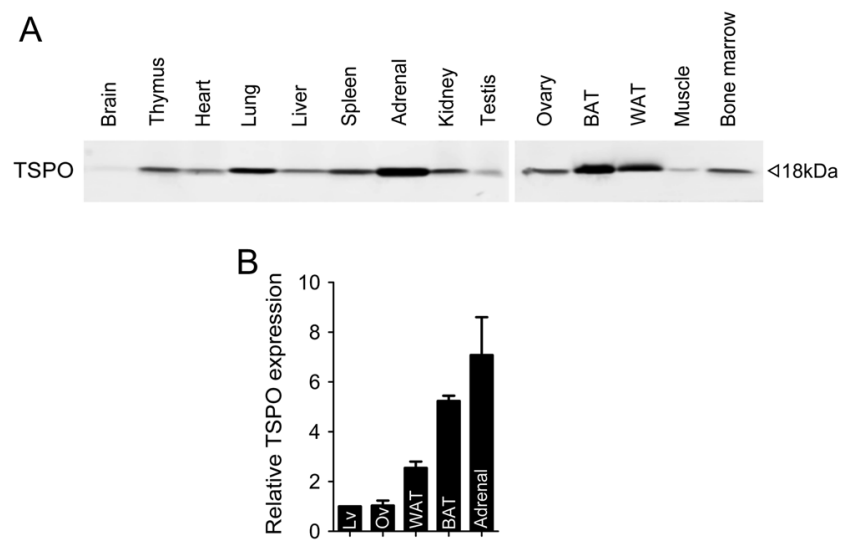

Figure 2

TSPO is highly expressed in tissues active in lipid metabolism.

(A) Representative Western blotting showing TSPO expression in 14 different tissues ( $75 \mu \mathrm{g}$ protein/sample). High expression of TSPO was observed in adrenal glands, followed by brown adipose tissue (BAT), white adipose tissue (WAT), lung and kidney. TSPO expression was weaker in other tissues and extremely low in the brain. (B) Compared with the liver (Lv), TSPO expression was similar in the ovary, 2.5-fold higher in the WAT, 5-fold higher in the BAT and 7-fold higher in adrenal glands (Adrenal). Republished with permission of the Endocrine Society, from Endocrinology, Tu LN, Zhao AH, Hussein M, Stocco DM \& Selvaraj V, volume 157, issue 3, 2016; permission conveyed through Copyright Clearance Center, Inc.

\section{Alternative perspectives for TSPO action in cells}

As TSPO research spans multiple fields/disciplines, attempts to explain its function have resulted in rather divergent yet unique perspectives. Some of these perspectives lack coherence in that they do not describe a unifying function for TSPO that is applicable to all cell types and/or the organism as a whole. Nevertheless, to provide a balanced view, we present evidence published in support of the different perspectives (Fig. 3), and when appropriate, indicate limitations and areas that require further exploration to refine and accelerate understanding toward the precise function of TSPO.

1. TSPO as a regulator of redox homeostasis: There are seemingly disparate mechanisms that have been proposed for TSPO in redox homeostasis. First, a putative TSPO-VDAC association is believed to induce ROS production. It was demonstrated that TSPO overexpression in cells induces mitochondrial ROS production, with a reverse trend observed after TSPO knockdown (Gatliff et al. 2014). However, there exists contrasting evidence that TSPO overexpression could dampen mitochondrial ROS production through an identical VDAC-dependent mechanism (Joo et al. 2012, 2015). Second, without the need for any protein interactions, it has been suggested

Published by Bioscientifica Ltd 
that TSPO could act to neutralize ROS. According to this hypothesis, the abundance of tryptophans in TSPO might react with ROS to generate tryptophan radicals (Guo et al. 2015). Third, a putative TSPO-NADPH oxidase 2 (NOX2) association has been proposed to play a role in ROS generation. In this model, TSPO is surmised to behave as a carrier or transporter for both cholesterol and heme (Guilarte et al. 2016). Fourth, it has been proposed that TSPO attenuates ROS signaling by modulating tetrapyrrole metabolism (Batoko et al. 2015).

Although all the above mechanisms are conceivable, they are attempts to explain TSPO function in cells based on effects that were initially observed using TSPO-binding drugs. Distinct from cells that consistently show high levels of TSPO expression (such as in the adrenal cortex and brown adipose tissue), these explanations almost always deal with cells that upregulate TSPO in response to different forms of stress. Therefore, it is possible that these interpretations may be confounded with cellular effects associated with the obvious link between stress and ROS production. The TSPO-VDAC relationship to ROS production has had contrasting results in similar TSPO overexpression studies (Gatliff et al. 2014, Joo et al. 2012, 2015). The TSPO-NOX2 association (Guilarte et al. 2016), remains a hypothesis. The finding that cardiac-specific Tspocs/s mice did not show any difference in the extent of ischemia reperfusion injury (Sileikyte et al. 2014), a pathology that is partly directed by myocardial NOX2 (Braunersreuther et al. 2013), seems to suggest that TSPO and NOX2 may not be a primary mechanism. Perhaps via an interaction of multiple pathways, it is not too surprising that pharmacological evidence has linked TSPO to a variety of mechanisms related to cardioprotection after ischemia reperfusion injury: preventing mitochondrial permeability (Obame et al. 2007), increasing activities of mitochondrial oxidative enzymes (Xiao et al. 2010) or by reducing mitochondrial cholesterol transport (Paradis et al. 2013). In TSPO-deficient MA-10 ${ }^{T s p o \Delta / \Delta}$ Leydig cells, loss of TSPO resulted in modest increases in ROS production (Tu et al. 2016), an observation that was linked to a shift in cellular metabolism (discussed below). Therefore, future studies carefully examining $\mathrm{Tspo}^{-/}$models to observe lossof-function are absolutely essential before an effect for TSPO in redox homeostasis can be confirmed.

2. TSPO as an enzyme for protoporphyrin IX degradation: Distinct from studies involving steroid production, porphyrins are considered endogenous

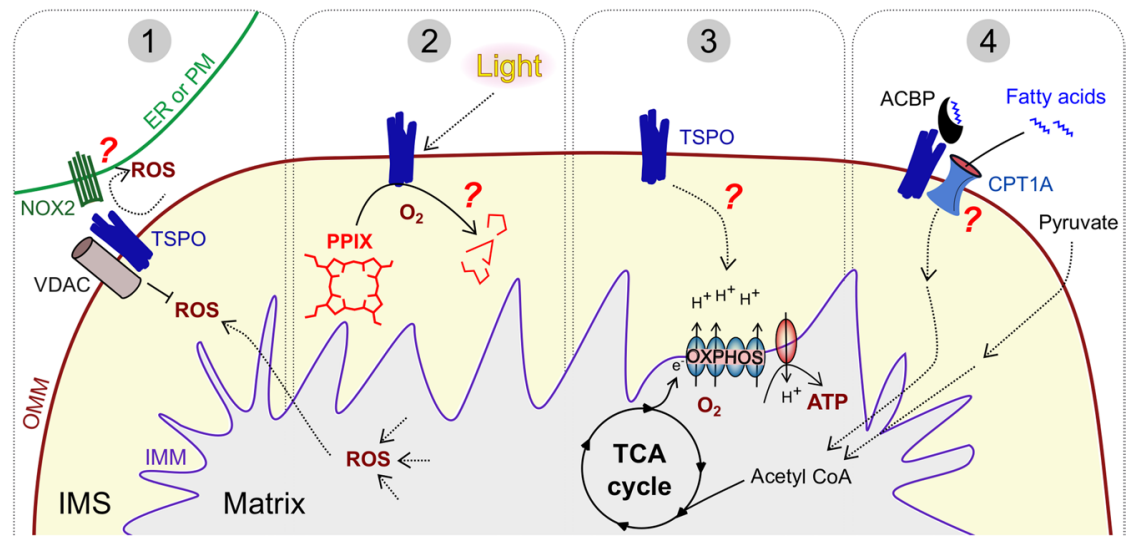

\section{Figure 3}

Alternative perspectives for TSPO action in cells. (1) TSPO as a regulator of redox homeostasis. It has been suggested that TSPO could interact with VDAC1 or NOX2 to induce production of ROS (Gatliff et al. 2014, Guilarte et al. 2016). On the contrary, the association of TSPO with VDAC1 (Joo et al. 2012, Joo et al. 2015), or TSPO by itself (Guo et al. 2015), could facilitate ROS neutralization. Although TSPO regulation of ROS is conceivable, at least as a secondary effect, functional evidence for the interactions and specific role of TSPO remains to be demonstrated. (2) TSPO as an enzyme for protoporphyrin IX degradation. Chemical catalysis of PPIX degradation by bacterial TSPO has been proposed as a function for TSPO (Ginter et al. 2013, Guo et al. 2015). The reaction rate was dependent on availability of light and oxygen. Lack of light in mammalian tissues that express high levels of TSPO like the adrenal glands raises question for the functional relevance and significance of this action. Nevertheless, conserved binding of TSPO to PPIX suggests a yet-to-be-determined action in cells. (3) TSPO as a regulator of oxygen consumption. Loss of TSPO had different effects in oxygen consumption rate in different cell types. Decreased oxygen consumption was observed in TSPO-deficient microglia and fibroblasts (Banati et al. 2014, Zhao et al. 2016), but no effects were observed in hepatocytes and Leydig cells (Sileikyte et al. 2014, Tu et al. 2016). These inconsistent effects are probably attributed to the diversity of mitochondrial types and energetic status of cells. Therefore, the direct mechanism remains unclear. (4) TSPO as a regulator of lipid metabolism. Several studies have correlated TSPO expression to functional changes in lipid metabolism (Wade et al. 2005, Leduc et al. 2011). It was identified that TSPO deletion could increase fatty acid oxidation in steroidogenic cells (Tu et al. 2016). Potential interaction of TSPO with ACBP or CPT1A could affects import of fatty acids into mitochondria for $\beta$-oxidation. All the above perspectives require additional investigation. 
ligands that bind TSPO (Verma et al. 1987). This porphyrinbinding property of TSPO appears highly conserved from bacteria to humans, but the function of this association continues to remain unclear. It was initially proposed that TSPO binds and transports protoporphyrin IX (PPIX), the precursor of heme, into the mitochondria (Wendler et al. 2003), a concept that emerged based on TSPO ligands being able to partially rescue cells from porphyrininduced phototoxicity (Ratcliffe \& Matthews 1995), and high levels of TSPO expression seen in the bone marrow (Taketani et al. 1994, Rampon et al. 2009). Although the property of PPIX binding to TSPO remains true, recent studies using $\mathrm{Tspo}^{-/-}$mice and cell lines have established that TSPO is not a porphyrin transporter for heme synthesis (Banati et al. 2014, Zhao et al. 2016). Using the bacterial Chlorobium tepidum TSPO purified in detergent, it was demonstrated that TSPO could induce rapid spectral changes to added PPIX indicative of chemical catalysis (Ginter et al. 2013). A similar observation has been reported for Bacillus cereus TSPO (Guo et al. 2015). However, the reaction rate was not proportional to TSPO concentration, but dependent on the availability of light and oxygen. Although this photo-oxidative PPIX degradation mediated by purified C. tepidum and B. cereus TSPO has been discussed in broad terms, there is no functional evidence that this occurs in any intact biological model systems. Moreover, the relevance of this light-dependent activity in deeper organs like the adrenal and brain remains questionable. Analysis of PPIX degradation/elimination as a time course in $\mathrm{Tspo}^{-/-}$mouse tissues and plasma suggests that this putative TSPOmediated degradation, at least in mammalian systems, is not a critical regulator of PPIX levels (Zhao et al. 2016). Although this observation does not validate a role for TSPO in PPIX degradation, it certainly does not discount a physiological function for the highly conserved TSPO-PPIX association. Use of $\mathrm{Tspo}^{-/}$models across different biological systems for investigating conserved properties in future studies may offer clues to uncovering specific functions for this association.

\section{TSPO as a regulator of oxygen consumption:} Evidence from lower organisms has indicated an oxygen-sensing function for TSPO (Yeliseev et al. 1997). In isolated primary microglia from Tspof//ll and $\mathrm{Tspo}^{-/}$mice, measurement of oxygen consumption rate (OCR) indicated that basal OCR was significantly lower in Tspo-/- microglia (Banati et al. 2014). In an independent study, OCR compared between Tspo-deficient mitochondria isolated from liver-specific
Tspocs/s mice and control Tspofl/tl mice showed no differences in OCR (Sileikyte et al. 2014). Although this contrast has been a topic of speculation with respect to the need for an intact cellular environment, and changes to metabolic demand in cells (reviewed in Gut 2015), it subsequently became clear that there was also no correlation between TSPO expression levels and OCR deficits observed in different cell types. Measurements of OCR in embryonic fibroblasts that express low levels of TSPO from $\mathrm{Tspo}^{-/-}$mice showed significantly diminished values compared with embryonic fibroblasts from Tspof//ll mice (Zhao et al. 2016). In contrast, measurements of OCR in steroidogenic MA-10 cells that express very high levels of TSPO showed no difference when compared with TSPO-deleted MA-10 cells (Tu et al. 2016). All these studies indicate that the change in OCR is a celltype-dependent indirect effect, inconsistent with TSPO expression levels, perhaps reflecting on the diversity of mitochondrial types, metabolism and energetic status of cells, and therefore does not reveal a direct mechanism for TSPO in regulating OCR.

Tspo-knockout studies in another in vivo model, Drosophila melanogaster, indicated that $\mathrm{Tspo}^{-/}$flies are without any abnormalities (Lin et al. 2014), similar to reports in mice (Banati et al. 2014, Tu et al. 2014). Interestingly, structures and cells in $\mathrm{Tspo}^{-/-}$flies showed increased survival after hydrogen peroxide exposure or $\gamma$-irradiation (Lin et al. 2014). In only male $\mathrm{Tspo}^{-/-}$flies, an extended lifespan was observed compared with male wild-type flies (Lin et al. 2014). Isolated Tspo-deficient mitochondria from these flies, irrespective of sex, showed a decreased rate of oxidative phosphorylation compared with $\mathrm{TspO}^{+/+}$mitochondria (Lin et al. 2014). Continued studies in $\mathrm{Tspo}^{-/}$D. melanogaster have linked TSPO function to ethanol sensitivity and tolerance (Lin et al. 2015). These seemingly disparate effects point to general mechanisms that surround mitochondrial function and do not pinpoint a specific indication for TSPO function.

Along the lines of cellular energy metabolism, a drug screen for identifying small molecules that induce expression of the gluconeogenic gene, phosphoenolpyruvate carboxykinase 1 (Pck1), using a transgenic zebrafish reporter line, PK11195 was identified as an agent that activates a state akin to fasting metabolism (Gut et al. 2013). Although this seems to be an exciting observation, it is unclear if the major effects observed are mediated through TSPO. This is because PK11195 is also known to bind the constitutive androstane receptor (CAR) (Li et al. 2008, Anderson et al. 2011), which can affect Pck1 transcription, together with other genes that affect energy

Published by Bioscientifica Ltd. 
metabolism (Ueda et al. 2002). The overall functions of CAR could also be linked to fasting metabolism (Maglich et al. 2004, Ding et al. 2006). Therefore, interpretation of PK11195 or other drug effects in the context of TSPO needs further affirmation using genetic models that can delineate off-target effects from specific effects.

4. TSPO as a regulator of lipid metabolism: Two independent exploratory studies identified Tspo as a candidate gene that could influence lipid metabolism. First, Tspo was identified as one of the six novel transcripts that showed robust positive correlation with adipocyte differentiation in a differential display RT-PCR screen (Wade et al. 2005). Second, Tspo was identified as one of the five genes that could influence triglyceride metabolism in an examination of quantitative trait loci between inbred mouse strains (Leduc et al. 2011). In agreement, recent examination of TSPO expression levels in different murine tissues indicated that high TSPO expression correlated with tissues active in lipid storage/metabolism, and was not specific for steroidogenic cells (Fig. 2) (Tu et al. 2016). As support for this correlation, it must be noted that steroidogenic cells also have substantial presence of lipid droplets. Measurement of energy metabolism in TSPO-deficient MA-10Tspos/ Leydig cells that do not show any deficits in steroid biosynthesis revealed a metabolic shift in substrate utilization from glucose to fatty acids compared with TSPO-expressing MA-10 cells. The MA-10 Tspos/ $L$ Leydig cells had higher levels of fatty acid oxidation and modest increases in ROS production compared with MA-10 controls (Tu et al. 2016).

Although the precise mechanism for this TSPO effect on lipid metabolism remains to be elucidated, there are a few plausible explanations: (1) Putative TSPO-ACBP interaction (Papadopoulos et al. 1991b) could be a direct link to fatty acid metabolism, perhaps affecting import at the OMM. ACBP is involved in fatty acid metabolism (Lee et al. 2007, Neess et al. 2011), and its expression mirrors TSPO in tissues (Tong et al. 1991, Toranzo et al. 1994). (2) Putative TSPO-VDAC1 interaction (McEnery et al. 1992). VDAC1 has been associated with the fatty acid transfer complex in the OMM (Lee et al. 2011a). (3) Physical changes to OMM properties due to loss of an abundant protein. There is evidence that the fatty acid transport protein CPT1A activity could be regulated by changes in OMM lipid composition and molecular order (Rao et al. 2011). Irrespective of the precise mechanism, a function for TSPO in fatty acid metabolism could explain its abundant presence in cells that are active in lipid storage. This function is also of particular interest in studying inflammatory cells and glia activation that result in TSPO upregulation, a mechanism that may be associated with the metabolic shift, as observed during immune cell activation (reviewed in Pearce \& Pearce 2013). These clues provide a new direction for TSPO function that is indeed worthy of further investigation.

\section{Neurosteroids and multiple sclerosis pathogenesis}

Multiple sclerosis (MS) is an autoimmune disease characterized by inflammatory lesions and ensuing neurodegeneration in parts of the CNS. These pathologic lesions have prominent upregulation of TSPO (Harberts et al. 2013), and therefore, use of TSPO as a biomarker for detecting MS lesions is of significant interest. Numerous studies have demonstrated a link between neurosteroids and neuroinflammatory diseases like multiple sclerosis (see reviews El-Etr et al. 2005, Kipp \& Beyer 2009, Noorbakhsh et al. 2014). Neurosteroid effects have been linked to promoting myelination (Melcangi et al. 1999, Ghoumari et al. 2003), inducing proliferation of neuroprogenitor cells (Ghoumari et al. 2005, Wang et al. 2005), reducing proinflammatory effects mediated by activated macrophages and glia (Ghezzi et al. 2000, Lee et al. 2011b) and reducing blood-brain barrier dysfunction (Ishrat et al. 2012). In human MS patients, neurosteroid levels were significantly reduced in the brain white matter, a finding that was consistent in EAE disease model in mice (Noorbakhsh et al. 2011). Therapeutic use of steroids has decreased the severity of EAE in animal models (Yates et al. 2010, Yu et al. 2010). TSPO upregulation is observed in microglia, infiltrating macrophages and astrocytes in response to injury/ inflammatory insults (Cosenza-Nashat et al. 2009). The popular explanation for TSPO upregulation at MS lesions has been that it could have a protective effect by limiting inflammatory damage through promoting neurosteroid production. TSPO-binding drugs were considered to enhance this mechanism (Daugherty et al. 2013, Ravikumar et al. 2016). In a preliminary investigation using hGFAP-cre driven $T s p o^{c \Delta / \Delta}$ mice with recombination expected in astrocytes and postnatal progenitors leading to neurons and oligodendrocytes, it was demonstrated that TSPO deficiency could ameliorate severity of EAE (Daugherty et al. 2016). TSPO is upregulated in 'reactive' astrocytes at EAE lesions, albeit in a different spatiotemporal pattern compared with microglia/macrophages (Daugherty et al. 2013).

Published by Bioscientifica Ltd. 
Although neurosteroid production was not directly measured in these astrocyte and postnatal neuronspecific Tspocs/s mice (Daugherty et al. 2016), the observation that TSPO presence is contributing to and not protective of the inflammatory pathology challenges the explanations linking TSPO and neurosteroid production. These emerging results from the use of TSPO-deficient mice in disease models not only confirm that TSPO is an important player in neuroinflammation, but also underscore the need to understand its core mechanism of action.

\section{Concluding remarks}

An early study that examined TSPO localization by autoradiography in whole-body rat sections concluded that expression was most concentrated in adrenals and skin, with substantial levels also evident in the heart, salivary glands, discrete regions of the kidney, epithelium of the lung, nasal and lingual epithelia, lining of the pulmonary artery, thymus, hair follicles, tooth buds and the bone marrow (Anholt et al. 1985b). We have come a long way from that initial observation, but functional interpretations for the past 30 years seem to be confounded by nonspecific outcomes and an apparent narrow focus toward determining TSPO function in divergent directions. This has also led to disparities in explaining TSPO function across different fields.

With initial links made to steroidogenesis, together with the increasing popularity of TSPO as a diagnostic marker and therapeutic target, the concept of its putative involvement in mitochondrial cholesterol import was perpetuated as a plausible explanation. In the field of neuroscience, this paradigm was adopted as the foundation for TSPO involvement in neurosteroid production. Recent definitive studies using both in vitro and in vivo genetic models have refuted the core basis of this explanation, and challenged the mechanisms underlying pharmacological effects observed using TSPObinding drugs. Although the genetic evidence is clear, the recurrent use of steroid production as a mechanism to explain TSPO actions has made this paradigm shift difficult to comprehend, mainly because there exists no clear explanation for the precise function for TSPO.

Use of pharmacological agents to establish TSPO function is highly problematic due to the structural variations in compounds, differences in binding affinity, nuances of binding sites, complexities of in vivo systems and idiosyncratic off-target effects. Interpreting results from studies that use TSPO-binding drugs requires caution to avoid promulgating misconstrued TSPO functions. In vivo and in vitro $\mathrm{Tspo}^{-/-}$models could serve as a great system to test for ligand specificity and TSPO-mediated pharmacological effects (Middleton et al. 2015).

The alternate perspectives on TSPO action presented in this review are based on current information available on the attempts to explain its function. From what we know of these proposed mechanisms, it is evident that additional studies are necessary to decipher the primary action of TSPO. It must also be noted that these proposals may not be correct and do not preclude TSPO involvement in other distinct cellular functions. The workings sought for TSPO function need to be a unifying action relevant for explaining functional properties in different tissues, and the organism as a whole.

In summary, although the TSPO link to neurosteroid production remains to be directly tested using genetic models, it is becoming increasingly clear that the relationship may not be direct. At the present time, studies on TSPO with a focus on defining its physiological function, which would ultimately provide insight into its action in the nervous system, are necessary before pharmacological intervention for therapeutic benefits can be approached with confidence.

\section{Declaration of interest}

The authors declare that there is no conflict of interest that could be perceived as prejudicing the impartiality of this review.

\section{Funding}

Research work in the lab is supported by startup funds from Cornell University (to $\vee \mathrm{S}$ ), and a fellowship from the Vietnam Education Foundation (to L N T).

Author contribution statement

V S and L N T wrote the manuscript.

\section{Acknowledgements}

The authors would like to thank Dr Doug Stocco, Texas Tech University Health Sciences Center, and Dr Susan Quirk, Cornell University, for their valuable feedback during the preparation of this manuscript.

\section{References}

Anderson LE, Dring AM, Hamel LD \& Stoner MA 2011 Modulation of constitutive androstane receptor (CAR) and pregnane $\mathrm{X}$ receptor (PXR) by 6-arylpyrrolo[2,1-d][1,5]benzothiazepine derivatives, ligands of peripheral benzodiazepine receptor (PBR). Toxicology Letters 202 148-154. (doi:10.1016/j.toxlet.2011.02.004)
๑ 2016 Society for Endocrinology Printed in Great Britain 
Anholt RR, De Souza EB, Kuhar MJ \& Snyder SH $1985 a$ Depletion of peripheral-type benzodiazepine receptors after hypophysectomy in rat adrenal gland and testis. European Journal of Pharmacology 110 41-46. (doi:10.1016/0014-2999(85)90026-3)

Anholt RR, De Souza EB, Oster-Granite ML \& Snyder SH $1985 b$ Peripheral-type benzodiazepine receptors: autoradiographic localization in whole-body sections of neonatal rats. Journal of Pharmacology and Experimental Therapeutics 233 517-526.

Anholt RR, Pedersen PL, De Souza EB \& Snyder SH 1986 The peripheral-type benzodiazepine receptor. Localization to the mitochondrial outer membrane. Journal of Biological Chemistry $261576-583$

Banati RB, Middleton RJ, Chan R, Hatty CR, Wai-Ying Kam W, Quin C, Graeber MB, Parmar A, Zahra D, Callaghan P, et al. 2014 Positron emission tomography and functional characterization of a complete PBR/TSPO knockout. Nature Communications 5 5452. (doi:10.1038/ ncomms6452)

Batoko H, Veljanovski V \& Jurkiewicz P 2015 Enigmatic translocator protein (TSPO) and cellular stress regulation. Trends in Biochemical Sciences 40 497-503. (doi:10.1016/j.tibs.2015.07.001)

Belelli D \& Lambert JJ 2005 Neurosteroids: endogenous regulators of the GABA(A) receptor. Nature Reviews. Neuroscience 6 565-575. (doi:10.1038/nrn1703)

Benavides J, Guilloux F, Allam DE, Uzan A, Mizoule J, Renault C, Dubroeucq MC, Gueremy C \& Le Fur G 1984 Opposite effects of an agonist, RO5-4864, and an antagonist, PK 11195, of the peripheral type benzodiazepine binding sites on audiogenic seizures in DBA/2J mice. Life Sciences 34 2613-2620. (doi:10.1016/00243205(84)90048-1)

Bernardi P, Rasola A, Forte M \& Lippe G 2015 The mitochondrial permeability transition pore: channel formation by F-ATP synthase, integration in signal transduction, and role in pathophysiology. Physiological Reviews 95 1111-1155. (doi:10.1152/ physrev.00001.2015)

Bernassau JM, Reversat JL, Ferrara P, Caput D \& Lefur G 1993 A 3D mode of the peripheral benzodiazepine receptor and its implication in intra mitochondrial cholesterol transport. Journal of Molecular Graphics $\mathbf{1 1}$ 236-244. (doi:10.1016/0263-7855(93)80003-A)

Bitran D, Foley M, Audette D, Leslie N \& Frye CA 2000 Activation of peripheral mitochondrial benzodiazepine receptors in the hippocampus stimulates allopregnanolone synthesis and produces anxiolytic-like effects in the rat. Psychopharmacology 151 64-71. (doi:10.1007/s002130000471)

Bloksgaard M, Bek S, Marcher AB, Neess D, Brewer J, Hannibal-Bach HK, Helledie T, Fenger C, Due M, Berzina Z, et al. 2012 The acyl-CoA binding protein is required for normal epidermal barrier function in mice. Journal of Lipid Research 53 2162-2174. (doi:10.1194/jlr.M029553)

Bogan RL, Davis TL \& Niswender GD 2007 Peripheral-type benzodiazepine receptor (PBR) aggregation and absence of steroidogenic acute regulatory protein (StAR)/PBR association in the mitochondrial membrane as determined by bioluminescence resonance energy transfer (BRET). Journal of Steroid Biochemistry and Molecular Biology 104 61-67. (doi:10.1016/j.jsbmb.2006.10.007)

Bose HS, Lingappa VR \& Miller WL 2002 Rapid regulation of steroidogenesis by mitochondrial protein import. Nature $\mathbf{4 1 7} 87-91$. (doi:10.1038/417087a)

Boujrad N, Hudson JR Jr \& Papadopoulos V 1993 Inhibition of hormonestimulated steroidogenesis in cultured Leydig tumor cells by a cholesterol-linked phosphorothioate oligodeoxynucleotide antisense to diazepam-binding inhibitor. PNAS 90 5728-5731. (doi:10.1073/ pnas.90.12.5728)

Braunersreuther V, Montecucco F, Asrih M, Pelli G, Galan K, Frias M, Burger F, Quindere AL, Montessuit C, Krause KH, et al. 2013 Role of NADPH oxidase isoforms NOX1, NOX2 and NOX4 in myocardial ischemia/reperfusion injury. Journal of Molecular and Cellular Cardiology 64 99-107. (doi:10.1016/j.yjmcc.2013.09.007)
Campanella M 2015 TSPO the unrested: challenged opinions of a resourceful mitochondrial protein. Trends in Endocrinology and Metabolism 26 333-334. (doi:10.1016/j.tem.2015.05.003)

Caron KM, Soo SC, Wetsel WC, Stocco DM, Clark BJ \& Parker KL 1997 Targeted disruption of the mouse gene encoding steroidogenic acute regulatory protein provides insights into congenital lipoid adrenal hyperplasia. PNAS 94 11540-11545. (doi:10.1073/pnas.94.21.11540)

Cavallaro S, Pani L, Guidotti A \& Costa E 1993 ACTH-induced mitochondrial DBI receptor (MDR) and diazepam binding inhibitor (DBI) expression in adrenals of hypophysectomized rats is not causeeffect related to its immediate steroidogenic action. Life Sciences $\mathbf{5 3}$ 1137-1147. (doi:10.1016/0024-3205(93)90550-M)

Charalampopoulos I, Remboutsika E, Margioris AN \& Gravanis A 2008 Neurosteroids as modulators of neurogenesis and neuronal survival. Trends in Endocrinology and Metabolism 19 300-307. (doi:10.1016/j. tem.2008.07.004)

Cheney DL, Uzunov D, Costa E \& Guidotti A 1995 Gas chromatographicmass fragmentographic quantitation of 3 alpha-hydroxy-5 alphapregnan-20-one (allopregnanolone) and its precursors in blood and brain of adrenalectomized and castrated rats. Journal of Neuroscience 15 4641-4650.

Cheng B, Hsu DK \& Kimura T 1985 Utilization of intramitochondrial membrane cholesterol by cytochrome P-450-dependent cholesterol side-chain cleavage reaction in bovine adrenocortical mitochondria: steroidogenic and non-steroidogenic pools of cholesterol in the mitochondrial inner membranes. Molecular and Cellular Endocrinology 40 233-243. (doi:10.1016/0303-7207(85)90179-0)

Chua SW, Kassiou M \& Ittner LM 2014 The translocator protein as a drug target in Alzheimer's disease. Expert Review of Neurotherapeutics 14 439-448. (doi:10.1586/14737175.2014.896201)

Churchill PF \& Kimura T 1979 Topological studies of cytochromes P-450scc and P-45011 beta in bovine adrenocortical inner mitochondrial membranes. Effects of controlled tryptic digestion. Journal of Biological Chemistry 254 10443-10448.

Clark BJ, Wells J, King SR \& Stocco DM 1994 The purification, cloning, and expression of a novel luteinizing hormone-induced mitochondrial protein in MA-10 mouse Leydig tumor cells. Characterization of the steroidogenic acute regulatory protein (StAR). Journal of Biological Chemistry $26928314-28322$.

Compagnone NA \& Mellon SH 2000 Neurosteroids: biosynthesis and function of these novel neuromodulators. Frontiers in Neuroendocrinology 21 1-56. (doi:10.1006/frne.1999.0188)

Compagnone NA, Bulfone A, Rubenstein JL \& Mellon SH 1995 Expression of the steroidogenic enzyme P450scc in the central and peripheral nervous systems during rodent embryogenesis. Endocrinology 136 2689-2696. (doi:10.1210/en.136.6.2689)

Corpechot C, Robel P, Axelson M, Sjovall J \& Baulieu EE 1981 Characterization and measurement of dehydroepiandrosterone sulfate in rat brain. PNAS 78 4704-4707. (doi:10.1073/pnas.78.8.4704)

Corpechot C, Synguelakis M, Talha S, Axelson M, Sjovall J, Vihko R, Baulieu EE \& Robel P 1983 Pregnenolone and its sulfate ester in the rat brain. Brain Research 270 119-125. (doi:10.1016/00068993(83)90797-7)

Cosenza-Nashat M, Zhao ML, Suh HS, Morgan J, Natividad R, Morgello S \& Lee SC 2009 Expression of the translocator protein of $18 \mathrm{kDa}$ by microglia, macrophages and astrocytes based on immunohistochemical localization in abnormal human brain. Neuropathology and Applied Neurobiology 35 306-328. (doi:10.1111/ j.1365-2990.2008.01006.x)

Costa B, Pini S, Gabelloni P, Da Pozzo E, Abelli M, Lari L, Preve M, Lucacchini A, Cassano GB \& Martini C 2009a The spontaneous Ala147Thr amino acid substitution within the translocator protein influences pregnenolone production in lymphomonocytes of healthy individuals. Endocrinology 150 5438-5445. (doi:10.1210/en.2009-0752)

Costa B, Pini S, Martini C, Abelli M, Gabelloni P, Landi S, Muti M, Gesi C, Lari L, Cardini A, et al. 2009b Ala147Thr substitution in translocator 
protein is associated with adult separation anxiety in patients with depression. Psychiatric Genetics 19 110-111. (doi:10.1097/ ypg.0b013e32832080f6)

Costa B, Da Pozzo E, Chelli B, Simola N, Morelli M, Luisi M, Maccheroni M, Taliani S, Simorini F, Da Settimo F, et al. 2011 Anxiolytic properties of a 2-phenylindolglyoxylamide TSPO ligand: stimulation of in vitro neurosteroid production affecting GABAA receptor activity. Psychoneuroendocrinology 36 463-472. (doi:10.1016/j. psyneuen.2010.07.021)

Da Settimo F, Simorini F, Taliani S, La Motta C, Marini AM, Salerno S, Bellandi M, Novellino E, Greco G, Cosimelli B, et al. 2008 Anxiolyticlike effects of N,N-dialkyl-2-phenylindol-3-ylglyoxylamides by modulation of translocator protein promoting neurosteroid biosynthesis. Journal of Medicinal Chemistry $\mathbf{5 1}$ 5798-5806. (doi:10.1021/jm8003224)

Daugherty DJ, Selvaraj V, Chechneva OV, Liu XB, Pleasure DE \& Deng W 2013 A TSPO ligand is protective in a mouse model of multiple sclerosis. EMBO Molecular Medicine 5 891-903. (doi:10.1002/ emmm.201202124)

Daugherty DJ, Chechneva O, Mayrhofer F \& Deng W 2016 The hGFAP-driven conditional TSPO knockout is protective in a mouse model of multiple sclerosis. Scientific Reports 6 22556. (doi:10.1038/ srep22556)

De Souza EB, Anholt RR, Murphy KM, Snyder SH \& Kuhar MJ 1985 Peripheral-type benzodiazepine receptors in endocrine organs: autoradiographic localization in rat pituitary, adrenal, and testis. Endocrinology 116 567-573. (doi:10.1210/endo-116-2-567)

Deane HW \& Greep RO 1946 A morphological and histochemical study of the rat's adrenal cortex after hypoph ysectomy, with comments on the liver. American Journal of Anatomy 79 117-145. (doi:10.1002/ (ISSN)1553-0795)

Ding X, Lichti K, Kim I, Gonzalez FJ \& Staudinger JL 2006 Regulation of constitutive androstane receptor and its target genes by fasting, cAMP, hepatocyte nuclear factor alpha, and the coactivator peroxisome proliferator-activated receptor gamma coactivator-1alpha. Journal of Biological Chemistry 281 26540-26551. (doi:10.1074/jbc.M600931200)

Do Rego JL, Seong JY, Burel D, Leprince J, Luu-The V, Tsutsui K, Tonon MC, Pelletier G \& Vaudry H 2009 Neurosteroid biosynthesis: enzymatic pathways and neuroendocrine regulation by neurotransmitters and neuropeptides. Frontiers in Neuroendocrinology 30 259-301. (doi:10.1016/j.yfrne.2009.05.006)

do Rego JL, Vaudry D \& Vaudry H 2015 The non-benzodiazepine anxiolytic drug etifoxine causes a rapid, receptor-independent stimulation of neurosteroid biosynthesis. PLOS ONE 10 e0120473. (doi:10.1371/journal.pone.0120473)

Do-Rego JL, Mensah-Nyagan AG, Feuilloley M, Ferrara P, Pelletier G \& Vaudry H 1998 The endozepine triakontatetraneuropeptide diazepambinding inhibitor [17-50] stimulates neurosteroid biosynthesis in the frog hypothalamus. Neuroscience 83 555-570. (doi:10.1016/S03064522(97)00362-X)

El-Etr M, Vukusic S, Gignoux L, Durand-Dubief F, Achiti I, Baulieu EE \& Confavreux C 2005 Steroid hormones in multiple sclerosis. Journal of the Neurological Sciences 233 49-54. (doi:10.1016/j.jns.2005.03.004)

Fan J, Rone MB \& Papadopoulos V 2009 Translocator protein 2 is involved in cholesterol redistribution during erythropoiesis. Journal of Biological Chemistry 284 30484-30497. (doi:10.1074/jbc. M109.029876)

Fan J, Lindemann P, Feuilloley MG \& Papadopoulos V 2012 Structural and functional evolution of the translocator protein $(18 \mathrm{kDa})$. Current Molecular Medicine 12 369-386. (doi:10.2174/1566524011207040369)

Fan J, Campioli E, Midzak A, Culty M \& Papadopoulos V 2015 Conditional steroidogenic cell-targeted deletion of TSPO unveils a crucial role in viability and hormone-dependent steroid formation. PNAS 112 7261-7266. (doi:10.1073/pnas.1502670112)

Ferguson JJ Jr 1963 Protein synthesis and adrenocorticotropin responsiveness. Journal of Biological Chemistry 238 2754-2759.
Ferzaz B, Brault E, Bourliaud G, Robert JP, Poughon G, Claustre Y, Marguet F, Liere P, Schumacher M, Nowicki JP, et al. 2002 SSR180575 (7-chloro-N,N,5-trimethyl-4-oxo-3-phenyl-3,5-dihydro-4Hpyridazino[4,5-b]indole-1 -acetamide), a peripheral benzodiazepine receptor ligand, promotes neuronal survival and repair. Journal of Pharmacology and Experimental Therapeutics 301 1067-1078. (doi:10.1124/jpet.301.3.1067)

File SE \& Lister RG 1983 The anxiogenic action of Ro 5-4864 is reversed by phenytoin. Neuroscience Letters 35 93-96. (doi:10.1016/03043940(83)90532-3)

File SE \& Pellow S 1985 The effects of PK 11195, a ligand for benzodiazepine binding sites, in animal tests of anxiety and stress. Pharmacology Biochemistry and Behavior 23 737-741. (doi:10.1016/0091-3057(85)90064-4)

Furukawa A, Miyatake A, Ohnishi T \& Ichikawa Y 1998 Steroidogenic acute regulatory protein (StAR) transcripts constitutively expressed in the adult rat central nervous system: colocalization of StAR, cytochrome P-450SCC (CYP XIA1), and 3beta-hydroxysteroid dehydrogenase in the rat brain. Journal of Neurochemistry $\mathbf{7 1}$ 2231-2238. (doi:10.1046/j.1471-4159.1998.71062231.x)

Gaigg B, Neergaard TB, Schneiter R, Hansen JK, Faergeman NJ, Jensen NA, Andersen JR, Friis J, Sandhoff R, Schroder HD, et al. 2001 Depletion of acyl-coenzyme A-binding protein affects sphingolipid synthesis and causes vesicle accumulation and membrane defects in Saccharomyces cerevisiae. Molecular Biology of the Cell 12 1147-1160. (doi:10.1091/ mbc.12.4.1147)

Garnier M, Boujrad N, Ogwuegbu SO, Hudson JR Jr \& Papadopoulos V 1994 The polypeptide diazepam-binding inhibitor and a higher affinity mitochondrial peripheral-type benzodiazepine receptor sustain constitutive steroidogenesis in the R2C Leydig tumor cell line. Journal of Biological Chemistry 269 22105-22112.

Gatliff J \& Campanella M 2016 TSPO: kaleidoscopic 18-kDa amid biochemical pharmacology, control and targeting of mitochondria. Biochemical Journal 473 107-121. (doi:10.1042/BJ20150899)

Gatliff J, East D, Crosby J, Abeti R, Harvey R, Craigen W, Parker P \& Campanella M 2014 TSPO interacts with VDAC1 and triggers a ROSmediated inhibition of mitochondrial quality control. Autophagy $\mathbf{1 0}$ 2279-2296. (doi:10.4161/15548627.2014.991665)

Gavish M, Bachman I, Shoukrun R, Katz Y, Veenman L, Weisinger G \& Weizman A 1999 Enigma of the peripheral benzodiazepine receptor. Pharmacological Reviews 51 629-650.

Ghezzi P, Santo ED, Sacco S, Foddi C, Barbaccia ML \& Mennini T 2000 Neurosteroid levels are increased in vivo after LPS treatment and negatively regulate LPS-induced TNF production. European Cytokine Network 11 464-469.

Ghoumari AM, Ibanez C, El-Etr M, Leclerc P, Eychenne B, O’Malley BW, Baulieu EE \& Schumacher M 2003 Progesterone and its metabolites increase myelin basic protein expression in organotypic slice cultures of rat cerebellum. Journal of Neurochemistry 86 848-859. (doi:10.1046/ j.1471-4159.2003.01881.x)

Ghoumari AM, Baulieu EE \& Schumacher M 2005 Progesterone increases oligodendroglial cell proliferation in rat cerebellar slice cultures. Neuroscience 135 47-58. (doi:10.1016/j.neuroscience.2005.05.023)

Ginter C, Kiburu I \& Boudker O 2013 Chemical catalysis by the translocator protein (18 kDa). Biochemistry 52 3609-3611. (doi:10.1021/bi400364z)

Gonzalez-Polo RA, Carvalho G, Braun T, Decaudin D, Fabre C, Larochette N, Perfettini JL, Djavaheri-Mergny M, Youlyouz-Marfak I, Codogno P, et al. 2005 PK11195 potently sensitizes to apoptosis induction independently from the peripheral benzodiazepin receptor. Oncogene 24 7503-7513. (doi:10.1038/sj.onc.1208907)

Gray PW, Glaister D, Seeburg PH, Guidotti A \& Costa E 1986 Cloning and expression of cDNA for human diazepam binding inhibitor, a natural ligand of an allosteric regulatory site of the gamma-aminobutyric acid type A receptor. PNAS 83 7547-7551. (doi:10.1073/pnas.83.19.7547) 
Guarneri P, Papadopoulos V, Pan B \& Costa E 1992 Regulation of pregnenolone synthesis in C6-2B glioma cells by $4^{\prime}$-chlorodiazepam. PNAS 89 5118-5122. (doi:10.1073/pnas.89.11.5118)

Guilarte TR, Loth MK \& Guariglia SR 2016 TSPO Finds NOX2 in microglia for redox homeostasis. Trends in Pharmacological Sciences $\mathbf{3 7}$ 334-343. (doi:10.1016/j.tips.2016.02.008)

Guo Y, Kalathur RC, Liu Q, Kloss B, Bruni R, Ginter C, Kloppmann E, Rost B \& Hendrickson WA 2015 Protein structure. Structure and activity of tryptophan-rich TSPO proteins. Science $\mathbf{3 4 7} 551-555$. (doi:10.1126/science.aaa1534)

Gut P 2015 Targeting mitochondrial energy metabolism with TSPO ligands. Biochemical Society Transactions 43 537-542. (doi:10.1042/ BST20150019)

Gut P, Baeza-Raja B, Andersson O, Hasenkamp L, Hsiao J, Hesselson D, Akassoglou K, Verdin E, Hirschey MD \& Stainier DY 2013 Wholeorganism screening for gluconeogenesis identifies activators of fasting metabolism. Nature Chemical Biology 9 97-104. (doi:10.1038/ nchembio.1136)

Harberts E, Datta D, Chen S, Wohler JE, Oh U \& Jacobson S 2013 Translocator protein $18 \mathrm{kDa}$ (TSPO) expression in multiple sclerosis patients. Journal of Neuroimmune Pharmacology 8 51-57. (doi:10.1007/ s11481-012-9397-5)

Hatty CR, Le Brun AP, Lake V, Clifton LA, Liu GJ, James M \& Banati RB 2014 Investigating the interactions of the $18 \mathrm{kDa}$ translocator protein and its ligand PK11195 in planar lipid bilayers. Biochimica et Biophysica Acta 1838 1019-1030. (doi:10.1016/j.bbamem.2013.12.013)

Hauet T, Yao ZX, Bose HS, Wall CT, Han Z, Li W, Hales DB, Miller WL, Culty M \& Papadopoulos V 2005 Peripheral-type benzodiazepine receptor-mediated action of steroidogenic acute regulatory protein on cholesterol entry into leydig cell mitochondria. Molecular Endocrinology 19 540-554. (doi:10.1210/me.2004-0307)

Haworth RA \& Hunter DR 1979 The Ca2+-induced membrane transition in mitochondria. II. Nature of the Ca2+ trigger site. Archives of Biochemistry and Biophysics 195 460-467. (doi:10.1016/00039861(79)90372-2)

Hu ZY, Bourreau E, Jung-Testas I, Robel P \& Baulieu EE 1987a Neurosteroids: oligodendrocyte mitochondria convert cholesterol to pregnenolone. PNAS 84 8215-8219. (doi:10.1073/pnas.84.23.8215)

Hu ZY, Bourreau E, Jung-Testas I, Robel P \& Baulieu EE 1987 b Neurosteroids: oligodendrocyte mitochondria convert cholesterol to pregnenolone. PNAS 84 8215-8219. (doi:10.1073/pnas.84.23.8215)

Hu MC, Hsu NC, El Hadj NB, Pai CI, Chu HP, Wang CK \& Chung BC 2002 Steroid deficiency syndromes in mice with targeted disruption of Cyp11a1. Molecular Endocrinology 16 1943-1950. (doi:10.1210/ me.2002-0055)

Hulce JJ, Cognetta AB, Niphakis MJ, Tully SE \& Cravatt BF 2013 Proteome-wide mapping of cholesterol-interacting proteins in mammalian cells. Nature Methods 10 259-264. (doi:10.1038/ nmeth.2368)

Hunter DR \& Haworth RA 1979a The Ca2+-induced membrane transition in mitochondria. I. The protective mechanisms. Archives of Biochemistry and Biophysics 195 453-459. (doi:10.1016/00039861(79)90371-0)

Hunter DR \& Haworth RA $1979 b$ The Ca2+-induced membrane transition in mitochondria. III. Transitional Ca2+ release. Archives of Biochemistry and Biophysics 195 468-477. (doi:10.1016/0003-9861(79)90373-4)

Ishrat T, Sayeed I, Atif F, Hua F \& Stein DG 2012 Progesterone is neuroprotective against ischemic brain injury through its effects on the phosphoinositide 3-kinase/protein kinase B signaling pathway. Neuroscience 210 442-450. (doi:10.1016/j.neuroscience.2012.03.008)

Jaremko L, Jaremko M, Giller K, Becker S \& Zweckstetter M 2014 Structure of the mitochondrial translocator protein in complex with a diagnostic ligand. Science 343 1363-1366. (doi:10.1126/science.1248725)

Jaremko M, Jaremko L, Giller K, Becker S \& Zweckstetter M 2015 a Structural Integrity of the A147T polymorph of mammalian TSPO. ChemBioChem 16 1483-1489. (doi:10.1002/cbic.201500217)
Jaremko M, Jaremko L, Jaipuria G, Becker S \& Zweckstetter M 2015 b Structure of the mammalian TSPO/PBR protein. Biochemical Society Transactions 43 566-571. (doi:10.1042/bst20150029)

Jaremko M, Jaremko L, Giller K, Becker S \& Zweckstetter M 2016 Backbone and side-chain resonance assignment of the A147T polymorph of mouse TSPO in complex with a high-affinity radioligand. Biomolecular NMR Assignments 10 79-83. (doi:10.1007/s12104-015-9642-y)

Jo Y \& Stocco DM 2004 Regulation of steroidogenesis and steroidogenic acute regulatory protein in $\mathrm{R} 2 \mathrm{C}$ cells by DAX-1 (dosage-sensitive sex reversal, adrenal hypoplasia congenita, critical region on the $\mathrm{X}$ chromosome, gene-1). Endocrinology 145 5629-5637. (doi:10.1210/ en.2004-0941)

Jo DH, Abdallah MA, Young J, Baulieu EE \& Robel P 1989 Pregnenolone, dehydroepiandrosterone, and their sulfate and fatty acid esters in the rat brain. Steroids 54 287-297. (doi:10.1016/0039-128X(89)90003-2)

Joo HK, Lee YR, Lim SY, Lee EJ, Choi S, Cho EJ, Park MS, Ryoo S, Park JB \& Jeon BH 2012 Peripheral benzodiazepine receptor regulates vascular endothelial activations via suppression of the voltage-dependent anion channel-1. FEBS Letters 586 1349-1355. (doi:10.1016/j. febslet.2012.03.049)

Joo HK, Lee YR, Kang G, Choi S, Kim CS, Ryoo S, Park JB \& Jeon BH 2015 The 18-kDa translocator protein inhibits vascular cell adhesion molecule-1 expression via inhibition of mitochondrial reactive oxygen species. Molecules and Cells 38 1064-1070.

Jung-Testas I, Hu ZY, Baulieu EE \& Robel P 1989 Neurosteroids: biosynthesis of pregnenolone and progesterone in primary cultures of rat glial cells. Endocrinology 125 2083-2091. (doi:10.1210/endo-125-4-2083)

Kelly-Hershkovitz E, Weizman R, Spanier I, Leschiner S, Lahav M, Weisinger G \& Gavish M 1998 Effects of peripheral-type benzodiazepine receptor antisense knockout on MA-10 Leydig cell proliferation and steroidogenesis. Journal of Biological Chemistry 273 5478-5483. (doi:10.1074/jbc.273.10.5478)

Kimura T \& Suzuki K 1965 Enzymatic reduction of non-heme iron protein (adrenodoxin) by reduced nicotinamide adenine dinucleotide phosphate. Biochemical and Biophysical Research Communications 20 373-379. (doi:10.1016/0006-291X(65)90585-1)

King SR, Manna PR, Ishii T, Syapin PJ, Ginsberg SD, Wilson K, Walsh LP, Parker KL, Stocco DM, Smith RG, et al. 2002 An essential component in steroid synthesis, the steroidogenic acute regulatory protein, is expressed in discrete regions of the brain. Journal of Neuroscience 22 10613-10620.

King SR, Ginsberg SD, Ishii T, Smith RG, Parker KL \& Lamb DJ 2004 The steroidogenic acute regulatory protein is expressed in steroidogenic cells of the day-old brain. Endocrinology 145 4775-4780. (doi:10.1210/ en.2003-1740)

Kinnally KW, Zorov DB, Antonenko YN, Snyder SH, McEnery MW \& Tedeschi H 1993 Mitochondrial benzodiazepine receptor linked to inner membrane ion channels by nanomolar actions of ligands. PNAS 90 1374-1378. (doi:10.1073/pnas.90.4.1374)

Kipp M \& Beyer C 2009 Impact of sex steroids on neuroinflammatory processes and experimental multiple sclerosis. Frontiers in Neuroendocrinology 30 188-200. (doi:10.1016/j.yfrne.2009.04.004)

Kita A, Kohayakawa H, Kinoshita T, Ochi Y, Nakamichi K, Kurumiya S, Furukawa K \& Oka M 2004 Antianxiety and antidepressant-like effects of AC-5216, a novel mitochondrial benzodiazepine receptor ligand. British Journal of Pharmacology 142 1059-1072. (doi:10.1038/ sj.bjp.0705681)

Koenig HL, Schumacher M, Ferzaz B, Thi AN, Ressouches A, Guennoun R, Jung-Testas I, Robel P, Akwa Y \& Baulieu EE 1995 Progesterone synthesis and myelin formation by Schwann cells. Science $\mathbf{2 6 8}$ 1500-1503. (doi:10.1126/science.7770777)

Kominami S, Shinzawa K \& Takemori S 1982 Purification and some properties of cytochrome P-450 specific for steroid 17 alphahydroxylation and C17-C20 bond cleavage from guinea pig adrenal microsomes. Biochemical and Biophysical Research Communications 109 916-921. (doi:10.1016/0006-291X(82)92027-7) 
Korneyev A, Pan BS, Polo A, Romeo E, Guidotti A \& Costa E 1993 Stimulation of brain pregnenolone synthesis by mitochondrial diazepam binding inhibitor receptor ligands in vivo. Journal of Neurochemistry $\mathbf{6 1}$ 1515-1524. (doi:10.1111/j.1471-4159.1993.tb13647.x)

Korkhov VM, Sachse C, Short JM \& Tate CG 2010 Three-dimensional structure of TspO by electron cryomicroscopy of helical crystals. Structure 18 677-687. (doi:10.1016/j.str.2010.03.001)

Kozikowski AP, Ma D, Brewer J, Sun S, Costa E, Romeo E \& Guidotti A 1993 Chemistry, binding affinities, and behavioral properties of a new class of "antineophobic" mitochondrial DBI receptor complex (mDRC) ligands. Journal of Medicinal Chemistry 36 2908-2920. (doi:10.1021/jm00072a010)

Krueger RJ \& Orme-Johnson NR 1983 Acute adrenocorticotropic hormone stimulation of adrenal corticosteroidogenesis. Discovery of a rapidly induced protein. Journal of Biological Chemistry 258 10159-10167.

Krueger KE \& Papadopoulos V 1990 Peripheral-type benzodiazepine receptors mediate translocation of cholesterol from outer to inner mitochondrial membranes in adrenocortical cells. Journal of Biological Chemistry 265 15015-15022.

Lacor P, Gandolfo P, Tonon MC, Brault E, Dalibert I, Schumacher M, Benavides J \& Ferzaz B 1999 Regulation of the expression of peripheral benzodiazepine receptors and their endogenous ligands during rat sciatic nerve degeneration and regeneration: a role for PBR in neurosteroidogenesis. Brain Research 815 70-80. (doi:10.1016/ S0006-8993(98)01105-6)

Lambert JJ, Cooper MA, Simmons RD, Weir CJ \& Belelli D 2009 Neurosteroids: endogenous allosteric modulators of GABA(A) receptors. Psychoneuroendocrinology 34 (Supplement 1) S48-S58.

Le Fur G, Vaucher N, Perrier ML, Flamier A, Benavides J, Renault C, Dubroeucq MC, Gueremy C \& Uzan A 1983 Differentiation between two ligands for peripheral benzodiazepine binding sites, [3H]RO54864 and [3H]PK 11195, by thermodynamic studies. Life Sciences 33 449-457. (doi:10.1016/0024-3205(83)90794-4)

Le Goascogne C, Robel P, Gouezou M, Sananes N, Baulieu EE \& Waterman M 1987 Neurosteroids: cytochrome P-450scc in rat brain. Science 237 1212-1215. (doi:10.1126/science.3306919)

Leduc MS, Hageman RS, Verdugo RA, Tsaih SW, Walsh K, Churchill GA \& Paigen B 2011 Integration of QTL and bioinformatic tools to identify candidate genes for triglycerides in mice. Journal of Lipid Research $\mathbf{5 2}$ 1672-1682. (doi:10.1194/jlr.M011130)

Lee L, DeBono CA, Campagna DR, Young DC, Moody DB \& Fleming MD 2007 Loss of the acyl-CoA binding protein (Acbp) results in fatty acid metabolism abnormalities in mouse hair and skin. Journal of Investigative Dermatology 127 16-23. (doi:10.1038/sj.jid.5700511)

Lee K, Kerner J \& Hoppel CL 2011a Mitochondrial carnitine palmitoyltransferase 1a (CPT1a) is part of an outer membrane fatty acid transfer complex. Journal of Biological Chemistry 286 25655-25662.

Lee M, Schwab C \& McGeer PL $2011 b$ Astrocytes are GABAergic cells that modulate microglial activity. Glia 59 152-165.

Li H \& Papadopoulos V 1998 Peripheral-type benzodiazepine receptor function in cholesterol transport. Identification of a putative cholesterol recognition/interaction amino acid sequence and consensus pattern. Endocrinology 139 4991-4997.

Li H, Yao Z, Degenhardt B, Teper G \& Papadopoulos V 2001 Cholesterol binding at the cholesterol recognition/ interaction amino acid consensus (CRAC) of the peripheral-type benzodiazepine receptor and inhibition of steroidogenesis by an HIV TAT-CRAC peptide. PNAS 98 1267-1272. (doi:10.1073/pnas.98.3.1267)

Li L, Chen T, Stanton JD, Sueyoshi T, Negishi M \& Wang H 2008 The peripheral benzodiazepine receptor ligand 1-(2-chlorophenylmethylpropyl)-3-isoquinoline-carboxamide is a novel antagonist of human constitutive androstane receptor. Molecular Pharmacology 74 443-453. (doi:10.1124/mol.108.046656)

Lin D, Chang YJ, Strauss JF 3rd \& Miller WL 1993 The human peripheral benzodiazepine receptor gene: cloning and characterization of alternative splicing in normal tissues and in a patient with congenital lipoid adrenal hyperplasia. Genomics 18 643-650. (doi:10.1016/ S0888-7543(05)80367-2)

Lin D, Sugawara T, Strauss JF 3rd, Clark BJ, Stocco DM, Saenger P, Rogol A \& Miller WL 1995 Role of steroidogenic acute regulatory protein in adrenal and gonadal steroidogenesis. Science 267 1828-1831.

Lin R, Angelin A, Da Settimo F, Martini C, Taliani S, Zhu S \& Wallace DC 2014 Genetic analysis of dTSPO, an outer mitochondrial membrane protein, reveals its functions in apoptosis, longevity, and A $\beta 42$ induced neurodegeneration. Aging Cell 13 507-518. (doi:10.1111/ acel.12200)

Lin R, Rittenhouse D, Sweeney K, Potluri P \& Wallace DC 2015 TSPO, a mitochondrial outer membrane protein, controls ethanol-related behaviors in Drosophila. PLoS Genetics 11 e1005366.

Liu J, Rone MB \& Papadopoulos V 2006 Protein-protein interactions mediate mitochondrial cholesterol transport and steroid biosynthesis. Journal of Biological Chemistry 281 38879-38893. (doi:10.1074/jbc. M608820200)

Liu GJ, Middleton RJ, Hatty CR, Kam WW, Chan R, Pham T, HarrisonBrown M, Dodson E, Veale K \& Banati RB 2014 The 18 kDa translocator protein, microglia and neuroinflammation. Brain Pathology 24 631-653. (doi:10.1111/bpa.12196)

Luo S, Mao C, Lee B \& Lee AS 2006 GRP78/BiP is required for cell proliferation and protecting the inner cell mass from apoptosis during early mouse embryonic development. Molecular and Cellular Biology 26 5688-5697. (doi:10.1128/MCB.00779-06)

Luo X, Sharma D, Inouye H, Lee D, Avila RL, Salmona M \& Kirschner DA 2007 Cytoplasmic domain of human myelin protein zero likely folded as beta-structure in compact myelin. Biophysical Journal 92 1585-1597. (doi:10.1529/biophysj.106.094722)

Ma L, Zhang H, Liu N, Wang PQ, Guo WZ, Fu Q, Jiao LB, Ma YQ \& Mi WD 2016 TSPO ligand PK11195 alleviates neuroinflammation and beta-amyloid generation induced by systemic LPS administration. Brain Research Bulletin 121 192-200. (doi:10.1016/j. brainresbull.2016.02.001)

Maaser K, Hopfner M, Jansen A, Weisinger G, Gavish M, Kozikowski AP, Weizman A, Carayon P, Riecken EO, Zeitz M, et al. 2001 Specific ligands of the peripheral benzodiazepine receptor induce apoptosis and cell cycle arrest in human colorectal cancer cells. British Journal of Cancer 85 1771-1780. (doi:10.1054/bjoc.2001.2181)

Maaser K, Sutter AP \& Scherubl H 2005 Mechanisms of mitochondrial apoptosis induced by peripheral benzodiazepine receptor ligands in human colorectal cancer cells. Biochemical and Biophysical Research Communications 332 646-652. (doi:10.1016/j. bbrc.2005.05.005)

Maglich JM, Watson J, McMillen PJ, Goodwin B, Willson TM \& Moore JT 2004 The nuclear receptor CAR is a regulator of thyroid hormone metabolism during caloric restriction. Journal of Biological Chemistry 279 19832-19838. (doi:10.1074/jbc.M313601200)

Mahata B, Zhang X, Kolodziejczyk AA, Proserpio V, Haim-Vilmovsky L, Taylor AE, Hebenstreit D, Dingler FA, Moignard V, Gottgens B, et al. 2014 Single-cell RNA sequencing reveals T helper cells synthesizing steroids de novo to contribute to immune homeostasis. Cell Reports 7 1130-1142. (doi:10.1016/j.celrep.2014.04.011)

Mandrup S, Jepsen R, Skott H, Rosendal J, Hojrup P, Kristiansen K \& Knudsen J 1993 Effect of heterologous expression of acyl-CoAbinding protein on acyl-CoA level and composition in yeast. Biochemical Journal 290 369-374. (doi:10.1042/bj2900369)

McCauley LD, Park CH, Lan NC, Tomich JM, Shively JE \& Gee KW 1995 Benzodiazepines and peptides stimulate pregnenolone synthesis in brain mitochondria. European Journal of Pharmacology 276 145-153. (doi:10.1016/0014-2999(95)00036-K)

McEnery MW, Snowman AM, Trifiletti RR \& Snyder SH 1992 Isolation of the mitochondrial benzodiazepine receptor: association with the voltage-dependent anion channel and the adenine nucleotide carrier. PNAS 89 3170-3174. (doi:10.1073/pnas.89.8.3170) 
Melcangi RC, Magnaghi V, Cavarretta I, Zucchi I, Bovolin P, D’Urso D \& Martini L 1999 Progesterone derivatives are able to influence peripheral myelin protein 22 and $\mathrm{P0}$ gene expression: possible mechanisms of action. Journal of Neuroscience Research 56 349-357. (doi:10.1002/(SICI)1097-4547(19990515)56:4<>1.0.CO;2-R)

Mellon SH \& Deschepper CF 1993 Neurosteroid biosynthesis: genes for adrenal steroidogenic enzymes are expressed in the brain. Brain Research 629 283-292. (doi:10.1016/0006-8993(93)91332-M)

Middleton RJ, Liu GJ \& Banati RB 2015 Guwiyang Wurra- 'Fire Mouse': a global gene knockout model for TSPO/PBR drug development, lossof-function and mechanisms of compensation studies. Biochemical Society Transactions 43 553-558. (doi:10.1042/BST20150039)

Midzak A \& Papadopoulos V 2014 Binding domain-driven intracellular trafficking of sterols for synthesis of steroid hormones, bile acids and oxysterols. Traffic 15 895-914. (doi:10.1111/tra.12177)

Midzak A, Rone M, Aghazadeh Y, Culty M \& Papadopoulos V 2011 Mitochondrial protein import and the genesis of steroidogenic mitochondria. Molecular and Cellular Endocrinology 336 70-79. (doi:10.1016/j.mce.2010.12.007)

Midzak A, Zirkin B \& Papadopoulos V 2015 Translocator protein: pharmacology and steroidogenesis. Biochemical Society Transactions 43 572-578. (doi:10.1042/BST20150061)

Miller WL \& Bose HS 2011 Early steps in steroidogenesis: intracellular cholesterol trafficking. Journal of Lipid Research 52 2111-2135. (doi:10.1194/jlr.R016675)

Mitsui K, Niwa T, Kawahara Y, Morimoto N, Ohmoto K, Kato M, Yamaura Y, Yoshimoto N, Suna H \& Katsumata S 2015 Antistress effects of ONO-2952, a novel translocator protein $18 \mathrm{kDa}$ antagonist, in rats. Neuropharmacology 99 51-66. (doi:10.1016/j. neuropharm.2015.07.011)

Mizrahi R, Rusjan PM, Kennedy J, Pollock B, Mulsant B, Suridjan I, De Luca V, Wilson AA \& Houle S 2012 Translocator protein (18 kDa) polymorphism (rs6971) explains in-vivo brain binding affinity of the PET radioligand [(18)F]-FEPPA. Journal of Cerebral Blood Flow and Metabolism 32 968-972. (doi:10.1038/jcbfm.2012.46)

Morohaku K, Pelton SH, Daugherty DJ, Butler WR, Deng W \& Selvaraj V 2014 Translocator protein/peripheral benzodiazepine receptor is not required for steroid hormone biosynthesis. Endocrinology 155 89-97. (doi:10.1210/en.2013-1556)

Mukhin AG, Papadopoulos V, Costa E \& Krueger KE 1989 Mitochondrial benzodiazepine receptors regulate steroid biosynthesis. PNAS $\mathbf{8 6}$ 9813-9816. (doi:10.1073/pnas.86.24.9813)

Murail S, Robert JC, Coic YM, Neumann JM, Ostuni MA, Yao ZX, Papadopoulos V, Jamin N \& Lacapere JJ 2008 Secondary and tertiary structures of the transmembrane domains of the translocator protein TSPO determined by NMR. Stabilization of the TSPO tertiary fold upon ligand binding. Biochimica et Biophysica Acta 1778 1375-1381. (doi:10.1016/j.bbamem.2008.03.012)

Nakajin S, Shinoda M \& Hall PF 1983 Purification and properties of 17 alpha-hydroxylase from microsomes of pig adrenal: a second C21 side-chain cleavage system. Biochemical and Biophysical Research Communications 111 512-517. (doi:10.1016/0006291X(83)90336-4)

Nakazawa F, Alev C, Shin M, Nakaya Y, Jakt LM \& Sheng G 2009 PBRL, a putative peripheral benzodiazepine receptor, in primitive erythropoiesis. Gene Expression Patterns 9 114-121. (doi:10.1016/j. gep.2008.09.005)

Neess D, Bloksgaard M, Bek S, Marcher AB, Elle IC, Helledie T, Due M, Pagmantidis V, Finsen B, Wilbertz J, et al. 2011 Disruption of the acylCoA-binding protein gene delays hepatic adaptation to metabolic changes at weaning. Journal of Biological Chemistry 286 3460-3472. (doi:10.1074/jbc.M110.161109)

Neess D, Bek S, Bloksgaard M, Marcher AB, Faergeman NJ \& Mandrup S 2013 Delayed hepatic adaptation to weaning in ACBP-/- mice is caused by disruption of the epidermal barrier. Cell Reports $\mathbf{5}$ 1403-1412. (doi:10.1016/j.celrep.2013.11.010)
Noorbakhsh F, Ellestad KK, Maingat F, Warren KG, Han MH, Steinman L, Baker GB \& Power C 2011 Impaired neurosteroid synthesis in multiple sclerosis. Brain 134 2703-2721. (doi:10.1093/ brain/awr200)

Noorbakhsh F, Baker GB \& Power C 2014 Allopregnanolone and neuroinflammation: a focus on multiple sclerosis. Frontiers in Cellular Neuroscience $\mathbf{8} 134$.

Obame FN, Zini R, Souktani R, Berdeaux A \& Morin D 2007 Peripheral benzodiazepine receptor-induced myocardial protection is mediated by inhibition of mitochondrial membrane permeabilization. Journal of Pharmacology and Experimental Therapeutics 323 336-345. (doi:10.1124/jpet.107.124255)

Ohgami RS, Campagna DR, Antiochos B, Wood EB, Sharp JJ, Barker JE \& Fleming MD 2005a nm1054: a spontaneous, recessive, hypochromic, microcytic anemia mutation in the mouse. Blood $1063625-3631$.

Ohgami RS, Campagna DR, Greer EL, Antiochos B, McDonald A, Chen J, Sharp JJ, Fujiwara Y, Barker JE \& Fleming MD 2005b Identification of a ferrireductase required for efficient transferrin-dependent iron uptake in erythroid cells. Nature Genetics 37 1264-1269.

Omura T, Sanders E, Estabrook RW, Cooper DY \& Rosenthal O 1966 Isolation from adrenal cortex of a nonheme iron protein and a flavoprotein functional as a reduced triphosphorpyridine nucleotidecytochrome P450 reductase. Archives of Biochemistry and Biophysics 117 660-673. (doi:10.1016/0003-9861(66)90108-1)

Owen DR, Lewis AJ, Reynolds R, Rupprecht R, Eser D, Wilkins MR, Bennacef I, Nutt DJ \& Parker CA 2011 Variation in binding affinity of the novel anxiolytic XBD173 for the $18 \mathrm{kDa}$ translocator protein in human brain. Synapse 65 257-259. (doi:10.1002/syn.v65.3)

Owen DR, Yeo AJ, Gunn RN, Song K, Wadsworth G, Lewis A, Rhodes C, Pulford DJ, Bennacef I, Parker CA, et al. 2012 An 18-kDa translocator protein (TSPO) polymorphism explains differences in binding affinity of the PET radioligand PBR28. Journal of Cerebral Blood Flow and Metabolism 32 1-5. (doi:10.1038/jcbfm.2011.147)

Ozaki H, Zoghbi SS, Hong J, Verma A, Pike VW, Innis RB \& Fujita M 2010 In vivo binding of protoporphyrin IX to rat translocator protein imaged with positron emission tomography. Synapse 64 649-653. (doi:10.1002/syn.v64:8)

Palmer M 2004 Cholesterol and the activity of bacterial toxins. FEMS Microbiology Letters 238 281-289. (doi:10.1111/j.1574-6968.2004. tb09768.x)

Pang S, Yang X, Wang M, Tissot R, Nino M, Manaligod J, Bullock LP \& Mason JI 1992 Inherited congenital adrenal hyperplasia in the rabbit: absent cholesterol side-chain cleavage cytochrome P450 gene expression. Endocrinology 131 181-186.

Papadopoulos V 1998 Structure and function of the peripheral-type benzodiazepine receptor in steroidogenic cells. Experimental Biology and Medicine 217 130-142. (doi:10.3181/00379727-217-44215)

Papadopoulos V 2014 On the role of the translocator protein (18-kDa) TSPO in steroid hormone biosynthesis. Endocrinology 155 15-20. (doi:10.1210/en.2013-2033)

Papadopoulos V \& Lecanu L 2009 Translocator protein (18 kDa) TSPO: an emerging therapeutic target in neurotrauma. Experimental Neurology 219 53-57. (doi:10.1016/j.expneurol.2009.04.016)

Papadopoulos V \& Miller WL 2012 Role of mitochondria in steroidogenesis. Best Practice \& Research Clinical Endocrinology \& Metabolism 26 771-790. (doi:10.1016/j.beem.2012.05.002)

Papadopoulos V, Mukhin AG, Costa E \& Krueger KE 1990 The peripheraltype benzodiazepine receptor is functionally linked to Leydig cell steroidogenesis. Journal of Biological Chemistry 265 3772-3779.

Papadopoulos V, Berkovich A \& Krueger KE 1991a The role of diazepam binding inhibitor and its processing products at mitochondrial benzodiazepine receptors: regulation of steroid biosynthesis. Neuropharmacology 30 1417-1423. (doi:10.1016/S00283908(11)80011-0)

Papadopoulos V, Berkovich A, Krueger KE, Costa E \& Guidotti A $1991 b$ Diazepam binding inhibitor and its processing products 
stimulate mitochondrial steroid biosynthesis via an interaction with mitochondrial benzodiazepine receptors. Endocrinology 129 1481-1488.

Papadopoulos V, Guarneri P, Kreuger KE, Guidotti A \& Costa E 1992 Pregnenolone biosynthesis in C6-2B glioma cell mitochondria: regulation by a mitochondrial diazepam binding inhibitor receptor. PNAS 89 5113-5117.

Papadopoulos V, Amri H, Boujrad N, Cascio C, Culty M, Garnier M, Hardwick M, Li H, Vidic B, Brown AS, et al. 1997a Peripheral benzodiazepine receptor in cholesterol transport and steroidogenesis. Steroids 62 21-28.

Papadopoulos V, Amri H, Li H, Boujrad N, Vidic B \& Garnier M 1997 b Targeted disruption of the peripheral-type benzodiazepine receptor gene inhibits steroidogenesis in the R2C Leydig tumor cell line. Journal of Biological Chemistry 272 32129-32135. (doi:10.1074/ jbc.272.51.32129)

Papadopoulos V, Aghazadeh Y, Fan J, Campioli E, Zirkin B \& Midzak A 2015 Translocator protein-mediated pharmacology of cholesterol transport and steroidogenesis. Molecular and Cellular Endocrinology 408 90-98. (doi:10.1016/j.mce.2015.03.014)

Paradis S, Leoni V, Caccia C, Berdeaux A \& Morin D 2013 Cardioprotection by the TSPO ligand 4 '-chlorodiazepam is associated with inhibition of mitochondrial accumulation of cholesterol at reperfusion. Cardiovascular Research 98 420-427. (doi:10.1093/cvr/ crt079)

Pearce EL \& Pearce EJ 2013 Metabolic pathways in immune cell activation and quiescence. Immunity 38 633-643. (doi:10.1016/j. immuni.2013.04.005)

Pedersen RC \& Brownie AC 1983 Cholesterol side-chain cleavage in the rat adrenal cortex: isolation of a cycloheximide-sensitive activator peptide. PNAS 80 1882-1886. (doi:10.1073/pnas.80.7.1882)

Pedersen RC \& Brownie AC 1987 Steroidogenesis-activator polypeptide isolated from a rat Leydig cell tumor. Science 236 188-190. (doi:10.1126/science.3563495)

Petralia SM \& Frye CA 2005 In the ventral tegmental area picrotoxin blocks FGIN 1-27-induced increases in sexual behavior of rats and hamsters. Psychopharmacology 178 174-182. (doi:10.1007/s00213004-2001-9)

Pezzi V, Mathis JM, Rainey WE \& Carr BR 2003 Profiling transcript levels for steroidogenic enzymes in fetal tissues. Journal of Steroid Biochemistry and Molecular Biology 87 181-189. (doi:10.1016/j. jsbmb.2003.07.006)

Pon LA, Hartigan JA \& Orme-Johnson NR 1986 Acute ACTH regulation of adrenal corticosteroid biosynthesis. Rapid accumulation of a phosphoprotein. Journal of Biological Chemistry 261 13309-13316.

Primofiore G, Da Settimo F, Taliani S, Simorini F, Patrizi MP, Novellino E, Greco G, Abignente E, Costa B, Chelli B, et al. 2004 N,N-dialkyl-2phenylindol-3-ylglyoxylamides. A new class of potent and selective ligands at the peripheral benzodiazepine receptor. Journal of Medicinal Chemistry 47 1852-1855. (doi:10.1021/jm030973k)

Provost AC, Pequignot MO, Sainton KM, Gadin S, Salle S, Marchant D, Hales DB \& Abitbol M 2003 Expression of SR-BI receptor and StAR protein in rat ocular tissues. Comptes Rendus Biologies 326 841-851. (doi:10.1016/j.crvi.2003.09.001)

Rampon C, Bouzaffour M, Ostuni MA, Dufourcq P, Girard C, Freyssinet JM, Lacapere JJ, Schweizer-Groyer G \& Vriz S 2009 Translocator protein $(18 \mathrm{kDa})$ is involved in primitive erythropoiesis in zebrafish. FASEB Journal 23 4181-4192. (doi:10.1096/fj.09-129262)

Rao RM, Jo Y, Babb-Tarbox M, Syapin PJ \& Stocco DM 2002 Regulation of steroid hormone biosynthesis in R2C and MA-10 Leydig tumor cells: role of the cholesterol transfer proteins StAR and PBR. Endocrine Research 28 387-394. (doi:10.1081/ERC-120016813)

Rao RM, Jo Y, Leers-Sucheta S, Bose HS, Miller WL, Azhar S \& Stocco DM 2003 Differential regulation of steroid hormone biosynthesis in R2C and MA-10 Leydig tumor cells: role of
SR-B1-mediated selective cholesteryl ester transport. Biology of Reproduction 68 114-121.

Rao JN, Warren GZ, Estolt-Povedano S, Zammit VA \& Ulmer TS 2011 An environment-dependent structural switch underlies the regulation of carnitine palmitoyltransferase 1A. Journal of Biological Chemistry 286 42545-42554. (doi:10.1074/jbc.M111.306951)

Ratcliffe SL \& Matthews EK 1995 Modification of the photodynamic action of delta-aminolaevulinic acid (ALA) on rat pancreatoma cells by mitochondrial benzodiazepine receptor ligands. British Journal of Cancer 71 300-305. (doi:10.1038/bjc.1995.60)

Ravikumar B, Crawford D, Dellovade T, Savinainen A, Graham D, Liere P, Oudinet JP, Webb M \& Hering H 2016 Differential efficacy of the TSPO ligands etifoxine and XBD-173 in two rodent models of multiple sclerosis. Neuropharmacology 108 229-237. (doi:10.1016/j. neuropharm.2016.03.053)

Rennert H, Cheng YJ \& Strauss JF 3rd 1993 Intracellular cholesterol dynamics in steroidogenic cells: a contemporary view. In The Ovary, pp 147-164. Eds P Leung \& Adashi EY. New York, NY, USA: Raven Press.

Robel P, Bourreau E, Corpechot C, Dang DC, Halberg F, Clarke C, Haug M, Schlegel ML, Synguelakis M, Vourch C, et al. 1987 Neurosteroids: 3 beta-hydroxy-delta 5-derivatives in rat and monkey brain. Journal of Steroid Biochemistry 27 649-655. (doi:10.1016/00224731(87)90133-6)

Romeo E, Auta J, Kozikowski AP, Ma D, Papadopoulos V, Puia G, Costa E \& Guidotti A 1992 2-Aryl-3-indoleacetamides (FGIN-1): a new class of potent and specific ligands for the mitochondrial DBI receptor (MDR). Journal of Pharmacology and Experimental Therapeutics 262 971-978.

Romeo E, Cavallaro S, Korneyev A, Kozikowski AP, Ma D, Polo A, Costa E \& Guidotti A 1993 Stimulation of brain steroidogenesis by 2-arylindole-3-acetamide derivatives acting at the mitochondrial diazepambinding inhibitor receptor complex. Journal of Pharmacology and Experimental Therapeutics 267 462-471.

Rupprecht R, Rammes G, Eser D, Baghai TC, Schule C, Nothdurfter C, Troxler T, Gentsch C, Kalkman HO, Chaperon F, et al. 2009 Translocator protein $(18 \mathrm{kD})$ as target for anxiolytics without benzodiazepine-like side effects. Science 325 490-493. (doi:10.1126/ science.1175055)

Rupprecht R, Papadopoulos V, Rammes G, Baghai TC, Fan J, Akula N, Groyer G, Adams D \& Schumacher M 2010 Translocator protein (18 kDa) (TSPO) as a therapeutic target for neurological and psychiatric disorders. Nature Reviews. Drug Discovery 9 971-988. (doi:10.1038/nrd3295)

Saalmann YB, Kirkcaldie MT, Waldron S \& Calford MB 2007 Cellular distribution of the GABAA receptor-modulating 3alpha-hydroxy, 5alpha-reduced pregnane steroids in the adult rat brain. Journal of Neuroendocrinology 19 272-284. (doi:10.1111/j.1365-2826.2006.01527.x)

Santoro A, Mattace Raso G, Taliani S, Da Pozzo E, Simorini F, Costa B, Martini C, Laneri S, Sacchi A, Cosimelli B, et al. 2016 TSPO-ligands prevent oxidative damage and inflammatory response in C6 glioma cells by neurosteroid synthesis. European Journal of Pharmaceutical Sciences 88 124-131. (doi:10.1016/j.ejps.2016.04.006)

Scarf AM, Luus C, Da Pozzo E, Selleri S, Guarino C, Martini C, Ittner LM \& Kassiou M 2012 Evidence for complex binding profiles and species differences at the translocator protein (TSPO) (18 kDa). Current Molecular Medicine 12 488-493. (doi:10.2174/1566524011207040488)

Schlichter R, Rybalchenko V, Poisbeau P, Verleye M \& Gillardin J 2000 Modulation of GABAergic synaptic transmission by the nonbenzodiazepine anxiolytic etifoxine. Neuropharmacology 39 1523-1535. (doi:10.1016/S0028-3908(99)00253-1)

Selleri S, Gratteri P, Costagli C, Bonaccini C, Costanzo A, Melani F, Guerrini G, Ciciani G, Costa B, Spinetti F, et al. 2005 Insight into 2-phenylpyrazolo[1,5-a]pyrimidin-3-yl acetamides as peripheral benzodiazepine receptor ligands: synthesis, biological evaluation http://joe.endocrinology-journals.org

DOI: $10.1530 / \mathrm{JOE}-16-0241$
๑ 2016 Society for Endocrinology Printed in Great Britain 
and 3D-QSAR investigation. Bioorganic \& Medicinal Chemistry 13 4821-4834. (doi:10.1016/j.bmc.2005.05.015)

Selvaraj V, Stocco DM \& Tu LN 2015 Minireview: translocator protein (TSPO) and steroidogenesis: a reappraisal. Molecular Endocrinology 29 490-501. (doi:10.1210/me.2015-1033)

Selvaraj V, Tu LN \& Stocco DM 2016 Crucial role reported for TSPO in viability and steroidogenesis is a misconception. Frontiers in Endocrinology 7 (doi:10.3389/fendo.2016.00091).

Seneviratne MS, Faccenda D, De Biase V \& Campanella M 2012 PK11195 inhibits mitophagy targeting the F1Fo-ATPsynthase in Bcl-2 knockdown cells. Current Molecular Medicine 12 476-482.

Serra M, Madau P, Chessa MF, Caddeo M, Sanna E, Trapani G, Franco M, Liso G, Purdy RH, Barbaccia ML, et al. 1999 2-Phenyl-imidazo[1,2-a] pyridine derivatives as ligands for peripheral benzodiazepine receptors: stimulation of neurosteroid synthesis and anticonflict action in rats. British Journal of Pharmacology 127 177-187. (doi:10.1038/sj.bjp.0702530)

Shikita M \& Hall PF 1973 Cytochrome P-450 from bovine adrenocortical mitochondria: an enzyme for the side chain cleavage of cholesterol. I. Purification and properties. Journal of Biological Chemistry 248 5598-5604.

Sierra A, Lavaque E, Perez-Martin M, Azcoitia I, Hales DB \& GarciaSegura LM 2003 Steroidogenic acute regulatory protein in the rat brain: cellular distribution, developmental regulation and overexpression after injury. European Journal of Neuroscience $\mathbf{1 8}$ 1458-1467. (doi:10.1046/j.1460-9568.2003.02872.x)

Sileikyte J, Blachly-Dyson E, Sewell R, Carpi A, Menabo R, Di Lisa F, Ricchelli F, Bernardi P \& Forte M 2014 Regulation of the mitochondrial permeability transition pore by the outer membrane does not involve the peripheral benzodiazepine receptor (TSPO). Journal of Biological Chemistry 289 13769-13781. (doi:10.1074/jbc. M114.549634)

Stocco DM \& Chen W 1991 Presence of identical mitochondrial proteins in unstimulated constitutive steroid-producing R2C rat Leydig tumor and stimulated nonconstitutive steroid-producing MA-10 mouse Leydig tumor cells. Endocrinology 128 1918-1926. (doi:10.1210/endo128-4-1918)

Stocco DM \& Clark BJ 1996 Regulation of the acute production of steroids in steroidogenic cells. Endocrine Reviews 17 221-244.

Stocco DM 2000 Intramitochondrial cholesterol transfer. Biochimica et Biophysica Acta 1486 184-197. (doi:10.1016/S13881981(00)00056-1)

Sutter AP, Maaser K, Hopfner M, Barthel B, Grabowski P, Faiss S, Carayon P, Zeitz M \& Scherubl H 2002 Specific ligands of the peripheral benzodiazepine receptor induce apoptosis and cell cycle arrest in human esophageal cancer cells. International Journal of Cancer 102 318-327. (doi:10.1002/ijc.v102:4)

Sutter AP, Maaser K, Hopfner M, Huether A, Schuppan D \& Scherubl H 2005 Cell cycle arrest and apoptosis induction in hepatocellular carcinoma cells by HMG-CoA reductase inhibitors. Synergistic antiproliferative action with ligands of the peripheral benzodiazepine receptor. Journal of Hepatology 43 808-816. (doi:10.1016/j. jhep.2005.04.010)

Taketani S, Kohno H, Okuda M, Furukawa T \& Tokunaga R 1994 Induction of peripheral-type benzodiazepine receptors during differentiation of mouse erythroleukemia cells. A possible involvement of these receptors in heme biosynthesis. Journal of Biological Chemistry 269 7527-7531.

Tong Y, Rheaume E, Simard J \& Pelletier G 1991 Localization of peripheral benzodiazepine binding sites and diazepam-binding inhibitor (DBI) mRNA in mammary glands and dimethylbenz(a) antracene (DMBA)-induced mammary tumors in the rat. Regulatory Peptides 33 263-273. (doi:10.1016/0167-0115(91)90229-A)

Toranzo D, Tong Y, Tonon MC, Vaudry H \& Pelletier G 1994 Localization of diazepam-binding inhibitor and peripheral type benzodiazepine binding sites in the rat ovary. Anatomy and Embryology 190 383-388.
Toyoshima K, Seta Y, Toyono T \& Kataoka S 2007 Immunohistochemical identification of cells expressing steroidogenic enzymes cytochrome $\mathrm{P} 450$ scc and $\mathrm{P} 450$ aromatase in taste buds of rat circumvallate papillae. Archives of Histology and Cytology 70 215-224. (doi:10.1679/ aohc.70.215)

Trapani G, Franco M, Latrofa A, Ricciardi L, Carotti A, Serra M, Sanna E, Biggio G \& Liso G 1999 Novel 2-phenylimidazo[1,2-a] pyridine derivatives as potent and selective ligands for peripheral benzodiazepine receptors: synthesis, binding affinity, and in vivo studies. Journal of Medicinal Chemistry 42 3934-3941. (doi:10.1021/ jm991035g)

Trapani G, Laquintana V, Denora N, Trapani A, Lopedota A, Latrofa A, Franco M, Serra M, Pisu MG, Floris I, et al. 2005 Structure-activity relationships and effects on neuroactive steroid synthesis in a series of 2-phenylimidazo[1,2-a]pyridineacetamide peripheral benzodiazepine receptors ligands. Journal of Medicinal Chemistry 48 292-305. (doi:10.1021/jm049610q)

Tsujishita Y \& Hurley JH 2000 Structure and lipid transport mechanism of a StAR-related domain. Nature Structural Biology 7 408-414. (doi:10.1038/75192)

Tsutsui K, Ukena K, Takase M, Kohchi C \& Lea RW 1999 Neurosteroid biosynthesis in vertebrate brains. Comparative Biochemistry and Physiology. Part C, Pharmacology, Toxicology \& Endocrinology 124 121-129. (doi:10.1016/S0742-8413(99)00065-1)

Tu LN, Morohaku K, Manna PR, Pelton SH, Butler WR, Stocco DM \& Selvaraj V 2014 Peripheral benzodiazepine receptor/translocator protein global knock-out mice are viable with no effects on steroid hormone biosynthesis. Journal of Biological Chemistry 289 27444-27454. (doi:10.1074/jbc.M114.578286)

Tu LN, Zhao AH, Stocco DM \& Selvaraj V 2015 PK11195 effect on steroidogenesis is not mediated through the translocator protein (TSPO). Endocrinology 156 1033-1039. (doi:10.1210/en.2014-1707)

Tu LN, Zhao AH, Hussein M, Stocco DM \& Selvaraj V 2016 Translocator protein (TSPO) affects mitochondrial fatty acid oxidation in steroidogenic cells. Endocrinology 157 1110-1121. (doi:10.1210/ en.2015-1795)

Ueda A, Hamadeh HK, Webb HK, Yamamoto Y, Sueyoshi T, Afshari CA, Lehmann JM \& Negishi M 2002 Diverse roles of the nuclear orphan receptor CAR in regulating hepatic genes in response to phenobarbital. Molecular Pharmacology 61 1-6. (doi:10.1124/ mol.61.1.1)

Ugale RR, Sharma AN, Kokare DM, Hirani K, Subhedar NK \& Chopde CT 2007 Neurosteroid allopregnanolone mediates anxiolytic effect of etifoxine in rats. Brain Research 1184 193-201. (doi:10.1016/j. brainres.2007.09.041)

Verleye M, Schlichter R \& Gillardin JM 1999 Interactions of etifoxine with the chloride channel coupled to the GABA(A) receptor complex. Neuroreport 10 3207-3210. (doi:10.1097/00001756-199910190-00015)

Verleye M, Akwa Y, Liere P, Ladurelle N, Pianos A, Eychenne B, Schumacher M \& Gillardin JM 2005 The anxiolytic etifoxine activates the peripheral benzodiazepine receptor and increases the neurosteroid levels in rat brain. Pharmacology, Biochemistry and Behavior 82 712-720. (doi:10.1016/j.pbb.2005.11.013)

Verma A, Nye JS \& Snyder SH 1987 Porphyrins are endogenous ligands for the mitochondrial (peripheral-type) benzodiazepine receptor. PNAS 84 2256-2260. (doi:10.1073/pnas.84.8.2256)

Wade FM, Wakade C, Mahesh VB \& Brann DW 2005 Differential expression of the peripheral benzodiazepine receptor and gremlin during adipogenesis. Obesity Research 13 818-822. (doi:10.1038/ oby.2005.93)

Walter RB, Pirga JL, Cronk MR, Mayer S, Appelbaum FR \& Banker DE 2005 PK11195, a peripheral benzodiazepine receptor (pBR) ligand, broadly blocks drug efflux to chemosensitize leukemia and myeloma cells by a pBR-independent, direct transportermodulating mechanism. Blood 106 3584-3593. (doi:10.1182/ blood-2005-02-0711) 
Wang JM, Johnston PB, Ball BG \& Brinton RD 2005 The neurosteroid allopregnanolone promotes proliferation of rodent and human neural progenitor cells and regulates cell-cycle gene and protein expression. Journal of Neuroscience 25 4706-4718. (doi:10.1523/ JNEUROSCI.4520-04.2005)

Wang M, Wey S, Zhang Y, Ye R \& Lee AS 2009 Role of the unfolded protein response regulator GRP78/BiP in development, cancer, and neurological disorders. Antioxidants \& Redox Signaling 11 2307-2316. (doi:10.1089/ars.2009.2485)

Warner M \& Gustafsson JA 1995 Cytochrome P450 in the brain: neuroendocrine functions. Frontiers in Neuroendocrinology 16 224-236. (doi:10.1006/frne.1995.1008)

Weissman BA, Cott J, Hommer D, Paul S \& Skolnick P 1984 Electrophysiological and pharmacological actions of the convulsant benzodiazepine Ro 5-4864. European Journal of Pharmacology 97 257-263. (doi:10.1016/0014-2999(84)90457-6)

Wendler G, Lindemann P, Lacapere JJ \& Papadopoulos V 2003 Protoporphyrin IX binding and transport by recombinant mouse PBR. Biochemical and Biophysical Research Communications $\mathbf{3 1 1}$ 847-852. (doi:10.1016/j.bbrc.2003.10.070)

Werry EL, Barron ML \& Kassiou M 2015 TSPO as a target for glioblastoma therapeutics. Biochemical Society Transactions 43 531-536. (doi:10.1042/BST20150015)

West LA, Horvat RD, Roess DA, Barisas BG, Juengel JL \& Niswender GD 2001 Steroidogenic acute regulatory protein and peripheral-type benzodiazepine receptor associate at the mitochondrial membrane. Endocrinology 142 502-505. (doi:10.1210/endo.142.1.8052)

Wey S, Luo B, Tseng CC, Ni M, Zhou H, Fu Y, Bhojwani D, Carroll WL \& Lee AS 2012 Inducible knockout of GRP78/BiP in the hematopoietic system suppresses Pten-null leukemogenesis and AKT oncogenic signaling. Blood 119 817-825. (doi:10.1182/blood-2011-06-357384)

Wisniewska M, Karlberg T, Lehtio L, Johansson I, Kotenyova T, Moche M \& Schuler H 2010 Crystal structures of the ATPase domains of four human Hsp70 isoforms: HSPA1L/Hsp70-hom, HSPA2/Hsp702, HSPA6/Hsp70B', and HSPA5/BiP/GRP78. PLoS ONE 5 e8625. (doi:10.1371/journal.pone.0008625)

Wolf L, Bauer A, Melchner D, Hallof-Buestrich H, Stoertebecker P, Haen E, Kreutz M, Sarubin N, Milenkovic VM, Wetzel CH, et al. 2015
Enhancing neurosteroid synthesis - relationship to the pharmacology of translocator protein (18 kDa) (TSPO) ligands and benzodiazepines. Pharmacopsychiatry 48 72-77. (doi:10.1055/s-0034-1398507)

Xiao J, Liang D, Zhang H, Liu Y, Li F \& Chen YH 2010 4 '-Chlorodiazepam, a translocator protein $(18 \mathrm{kDa})$ antagonist, improves cardiac functional recovery during postischemia reperfusion in rats. Experimental Biology and Medicine 235 478-486. (doi:10.1258/ ebm.2009.009291)

Yang G, Xu H, Li Z \& Li F 2014 Interactions of caveolin-1 scaffolding and intramembrane regions containing a CRAC motif with cholesterol in lipid bilayers. Biochimica et Biophysica Acta 1838 2588-2599. (doi:10.1016/j.bbamem.2014.06.018)

Yates MA, Li Y, Chlebeck P, Proctor T, Vandenbark AA \& Offner H 2010 Progesterone treatment reduces disease severity and increases IL-10 in experimental autoimmune encephalomyelitis. Journal of Neuroimmunology 220 136-139. (doi:10.1016/j.jneuroim.2010.01.013)

Yeliseev AA, Krueger KE \& Kaplan S 1997 A mammalian mitochondrial drug receptor functions as a bacterial "oxygen" sensor. PNAS 94 5101-5106. (doi:10.1073/pnas.94.10.5101)

Yu HJ, Fei J, Chen XS, Cai QY, Liu HL, Liu GD \& Yao ZX 2010 Progesterone attenuates neurological behavioral deficits of experimental autoimmune encephalomyelitis through remyelination with nucleus-sublocalized Olig1 protein. Neuroscience Letters 476 42-45. (doi:10.1016/j.neulet.2010.03.079)

Zhang MR, Kumata K, Maeda J, Yanamoto K, Hatori A, Okada M, Higuchi M, Obayashi S, Suhara T \& Suzuki K 2007 11C-AC-5216: a novel PET ligand for peripheral benzodiazepine receptors in the primate brain. Journal of Nuclear Medicine 48 1853-1861. (doi:10.2967/ jnumed.107.043505)

Zhang LM, Qiu ZK, Zhao N, Chen HX, Liu YQ, Xu JP, Zhang YZ, Yang RF \& Li YF 2014 Anxiolytic-like effects of YL-IPA08, a potent ligand for the translocator protein $(18 \mathrm{kDa})$ in animal models of post-traumatic stress disorder. International Journal of Neuropsychopharmacology 17 1659-1669. (doi:10.1017/s1461145714000479)

Zhao AH, Tu LN, Mukai C, Sirivelu MP, Pillai VV, Morohaku K, Cohen R \& Selvaraj V 2016 Mitochondrial translocator protein (TSPO) function is not essential for heme biosynthesis. Journal of Biological Chemistry 291 1591-1603. (doi:10.1074/jbc.m115.686360)

Received in final form 8 July 2016

Accepted 15 July 2016

Accepted Preprint published online 15 July 2016
() 2016 Society for Endocrinology Printed in Great Britain 